\title{
Novel Cinnamyl Hydroxyamides and 2-Aminoanilides as Histone Deacetylase Inhibitors: Apoptotic Induction and Cytodifferentiation Activity
}

\author{
Sergio Valente, ${ }^{[a]}$ Maria Tardugno, ${ }^{[a]}$ Mariarosaria Conte, ${ }^{[b]}$ Roberto Cirilli, ${ }^{[c]}$ Andrea Perrone, ${ }^{[a]}$ \\ Rino Ragno, ${ }^{[\mathrm{a}]}$ Silvia Simeoni, ${ }^{[\mathrm{a}, \mathrm{h}]}$ Anna Tramontano, ${ }^{[\mathrm{d}]}$ Silvio Massa ${ }^{[\mathrm{e}]}$ Angela Nebbioso, ${ }^{[\mathrm{b}]}$ \\ Marco Miceli, ${ }^{[b]}$ Gianluigi Franci, ${ }^{[b, g]}$ Gerald Brosch, ${ }^{[f]}$ Lucia Altucci, $^{*[b, g]}$ and Antonello Mai ${ }^{*[a]}$
}

Four novel series of cinnamyl-containing histone deacetylase (HDAC) inhibitors 1-4 are described, containing hydroxamate (1 and $\mathbf{3}$ ) or 2-aminoanilide (2 and 4 ) derivatives. When screened against class I (maize HD1-B and human HDAC1) and class II (maize HD1-A and human HDAC4) HDACs, most hydroxamates and 2-aminoanilides displayed potent and selective inhibition toward class I enzymes. Immunoblotting analyses performed in U937 leukemia cells generally revealed high acetyl$\mathrm{H} 3$ and low acetyl- $\alpha$-tubulin levels. Exceptions are compounds $\mathbf{3} \mathbf{f}-\mathbf{i}, \mathbf{3} \mathbf{m}-\mathbf{0}$, and $\mathbf{4} \mathbf{k}$, which showed higher tubulin acetylation than SAHA. In U937 cells, cell-cycle blockade in either the $G_{2} / M$ or $G_{1} / S$ phase was observed with 1-4. Five hydroxamates (compounds $\mathbf{1} \mathbf{h}-\mathbf{l}$ ) effected a two- to greater than threefold greater percent apoptosis than SAHA, and in the CD11c cytodifferentiation test some 2-aminoanilides belonging to both series 2 and 4 were more active than MS-275. The highestscoring derivatives in terms of apoptosis $(\mathbf{1} \mathbf{k}, \mathbf{1} \mathbf{I})$ or cytodifferentiation ( 2 c, 4 n) also showed antiproliferative activity in U937 cells, thus representing valuable tools for study in other cancer contexts.

\section{Introduction}

Chromatin remodeling is one of the most important mechanisms in epigenetic regulation of gene expression. The dynamic higher-ordered structure of nucleosomes defines distinct levels of chromatin organization and, subsequently, gene activity. ${ }^{[1-3]}$ Histone deacetylases (HDACs) catalyze the hydrolysis of the $\varepsilon$-acetylamino groups of acetylated Lys residues in $\mathrm{H} 3$ and $\mathrm{H} 4$ histone tails, and in this way they regulate the switch from euchromatin (transcriptionally active) to heterochromatin (transcriptionally silent). ${ }^{[4-7]}$ Such chemical activity makes HDACs an important target for cancer therapy ${ }^{[8]}$ Indeed, HDAC inhibitors (HDACi) activate the transcription of a small set of genes and regulate cell proliferation and cell-cycle progression, leading to growth arrest, apoptosis, and/or differentiation both in cancer cells and in animal tumor models. ${ }^{[9-13]}$ Since the discovery that the antileukemia properties of trichostatin A (TSA) are due to inhibition of HDAC enzymes, a large number of structurally different HDACi have been reported as novel antiproliferative and cytodifferentiating agents. Among them, vorinostat (suberoylanilide hydroxamic acid, SAHA) and romidepsin (FK-228) have been approved by the US Food and Drug Administration (FDA) for the treatment of refractory cutaneous T-cell lymphoma (CTCL). ${ }^{[14,15]}$ In addition to vorinostat and romidepsin, valproic acid (VPA), panobinostat (LBH589), belinostat (PDX101), givinostat (ITF2357), entinostat (MS-275), and mocetinostat (MGCD0103) (Figure 1) are in phase II/III clinical trials for the therapy of hematological disorders as well as solid tumors. ${ }^{[16-18]}$ The pharmacophore model for HDACi includes a cap group (CAP) able to interact with the rim of the catalytic tunnel of the enzyme, a polar connection unit (CU) linked to a hydrophobic spacer (HS) which allows the molecule to lie in the tunnel, and a zinc binding group (ZBG) able to complex the $\mathrm{Zn}^{2+}$ ion at the bottom of the cavity. ${ }^{[19,20]}$ In addition to TSA

[a] Dr. S. Valente, Dr. M. Tardugno, Dr. A. Perrone, Dr. R. Ragno, Dr. S. Simeoni, Prof. A. Mai

Istituto Pasteur - Fondazione Cenci Bolognetti, Dipartimento di Chimica e Tecnologie del Farmaco, Università degli Studi di Roma "La Sapienza" P.le A. Moro 5, 00185 Roma (Italy)

Fax: (+39) 06-49693268

E-mail:antonello.mai@uniroma1.it

[b] Dr. M. Conte, Dr. A. Nebbioso, Dr. M. Miceli, Dr. G. Franci, Prof. L. Altucci Dipartimento di Patologia Generale, Seconda Università degli Studi di Napoli, vico L. De Crecchio 7, 80138 Napoli (Italy)

Fax: (+39) 081-450169 E-mail: lucia.altucci@unina2.it

[c] Dr. R. Cirilli

Dipartimento del Farmaco, Istituto Superiore di Sanità Via Regina Elena 299, 00161 Roma (Italy)

[d] Prof. A. Tramontano Dipartimento di Scienze Biochimiche, A. Rossi Fanelli, Università degli Studi di Roma "La Sapienza", P.le A. Moro 5, 00185 Roma (Italy)

[e] Prof. S. Massa

Dipartimento Farmaco Chimico Tecnologico, Università degli Studi di Siena via A. Moro, 53100 Siena (Italy)

[f] Prof. G. Brosch

Division of Molecular Biology, Biocenter, Innsbruck Medical University Fritz-Preglstrasse 3, 6020 Innsbruck (Austria)

[g] Dr. G. Franci, Prof. L. Altucci IGB-CNR, Via P. Castellino Napoli (Italy)

[h] Dr. S. Simeoni

Current address: Dipartimento di Scienze Biochimiche, A. Rossi Fanelli,Università degli Studi di Roma "La Sapienza" P.le A. Moro 5, 00185 Roma (Italy)

Supporting information for this article is available on the WWW under http://dx.doi.org/10.1002/cmdc.201000535. 
<smiles>CCCC(CCC)C(=O)O</smiles><smiles>CCCCCNCc1ccc(/C=C/C(=O)OO)cc1</smiles>

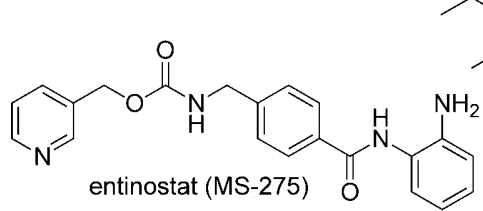<smiles>COc1ccc(C(=O)Nc2ccccc2N)cc1</smiles>

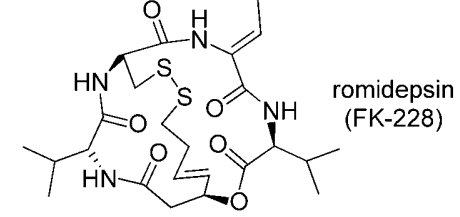

agent, whereas the benzamide MS-275 preferably shows high differentiation properties. ${ }^{[46]}$

The new compounds were screened against human HDAC1 and maize HD1-B (class I HDACs), and human HDAC4 and maize HD1-A (class lla HDACs), to assess their inhibitory activities and selectivity. Functional assays for testing the capability of compounds 1-4 to increase the acetylation levels of histone $\mathrm{H} 3$ and $\alpha$-tubulin in human leukemia U937 cells were determined, together with induction of the tumor suppressor protein p $21^{\text {WAF1/CIP1. }}$. Moreover, in U937 leukemia cells the effects of

Figure 1. HDACi currently in clinical trials as anticancer agents.

and SAHA, the two prototypes of natural and synthetic HDACi, which present an aliphatic chain as $\mathrm{HS}$, a number of $\mathrm{HDACi}$ carrying the cinnamyl moiety as HS has been described so far, starting from the SAHA-related hybrid polar compound cinnamyl bishydroxamic acid (CBHA). ${ }^{[21-28]}$ Among them, (S)HDAC42 ${ }^{[29]}$ was described as a novel HDACi highly active in prostate cancer, in hepatocellular carcinoma, in ovarian cancer, and able to sensitize prostate cancer cells to DNA-damaging agents through Ku70 acetylation. ${ }^{[30-34]}$ Moreover, the cited belinostat and panobinostat (Figure 1) are two examples of cinnamyl-containing HDACi actually in clinical trials for the treatment of many forms of tumors. ${ }^{[35,36]}$

We started our work on the design, synthesis, and biological evaluation of HDACi with some aroylpyrrolyl hydroxamates (APHAs), characterized by an aroyl portion as CAP $+\mathrm{CU}$, a pyrrylacrylic moiety as $\mathrm{HS}$, and the hydroxamate group as ZBG. ${ }^{[37-42]}$ Afterward, by replacing the pyrrole nucleus with the benzene ring, we reported two different series of cinnamyl hydroxamates, the $\mathrm{N}$-hydroxy-3-(2-, 3-, and 4-aroylaminophenyl)acrylamides $^{[43]}$ and the N-hydroxy-3-(4-(3-oxo-3-phenylprop-1enyl)phenyl)acrylamides (Figure 2), ${ }^{[44,45]}$ acting as anticancer agents through HDAC inhibition. Following our previous research on cinnamyl compounds, ${ }^{[43-45]}$ herein we report the synthesis and enzyme and in vitro evaluation of new arylacetylamino- and arylmethylaminocinnamyl hydroxamates and 2-aminoanilides (1-4), tested as HDACi and pro-apoptotic, antiproliferative, and/or cytodifferentiating agents (Figure 2). In particular, we inserted at the 4-position of the cinnamyl moiety, chosen as a HS, some arylacetylamino portions carrying a alkyl/aryl/arylalkyl substituent at the methylene group (compounds 1 and 2), or alternatively a wide range of (hetero)arylmethylamino groups (compounds 3 and 4) (CAP + CU groups). In addition, the arylacetylamino- and arylmethylaminocinnamyl compounds were prepared both as hydroxamates (1 and 3) and 2-aminoanilides (2 and 4) (ZBGs: $-\mathrm{CONHOH}$ or - $\mathrm{CONH}(2-$ $\left.\mathrm{NH}_{2}\right) \mathrm{Ph}$ ). Indeed, when tested in human leukemia U937 cells at $5 \mu \mathrm{M}$ for $30 \mathrm{~h}$, the hydroxamate SAHA is a typical apoptotic

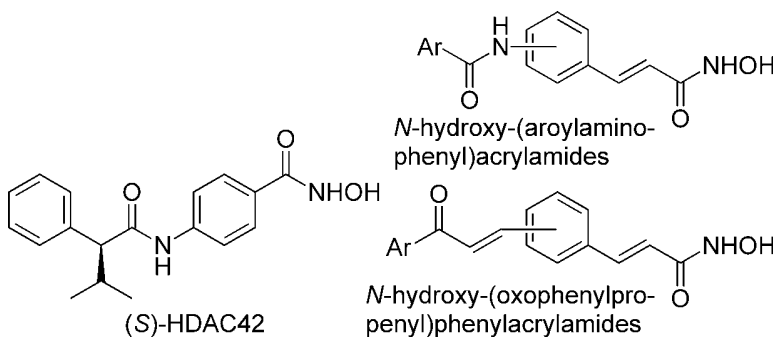<smiles>[R]C(=O)Nc1ccc(/C=C/C(=O)NO)cc1</smiles><smiles>[R10]C(=O)Nc1ccc(/C=C/C(=O)Nc2ccccc2N)cc1</smiles>

$\mathrm{R}=\mathrm{PhCHX}-, \mathrm{NaphCHX}-; \mathrm{X}=\mathrm{H}$, alkyl, $\mathrm{OCH}_{3}, \mathrm{Ph}, \mathrm{PhCH}_{2}$<smiles>[R]CNc1ccc(/C=C/C(=O)NO)cc1</smiles>

Figure 2. (S)-HDAC42 and cinnamyl-containing HDACi.

compounds 1-4 on cell cycle, apoptosis induction, proliferation, and granulocytic differentiation were established. SAHA, MS-275, and HDAC42 were prepared and included in the assays as reference drugs.

\section{Results and Discussion}

\section{Chemistry}

The title compounds were prepared starting from the key intermediate ethyl 4-aminocinnamate hydrochloride, ${ }^{[43]}$ that was treated with the properly substituted arylacetyl chlorides in the presence of triethylamine to afford the ethyl 3-(4-(2-arylacetamido)phenyl)acrylates $\mathbf{5} \mathbf{a}-\mathbf{n}$. Alternatively, the ethyl 4-aminocinnamate hydrochloride was condensed with the appropri- 
ate aldehydes to obtain the aldimine intermediates that were reduced to the ethyl 3-(4-(arylmethylamino)phenyl)acrylates 7 a-o with sodium cyanoborohydride. The ethyl esters $\mathbf{5}$ and 7 were hydrolyzed in basic medium to the related acrylic acids 6 and 8 , respectively. Further reaction of these 3-(4-(2-arylacetamido)- or 3-(4-(arylmethylamino)phenyl)acrylic acids ( $\mathbf{6} \mathbf{a}-\mathbf{n}$ or $8 \mathbf{a}-\mathbf{0}$, respectively) with 1 ) ethyl chloroformate and triethylamine, 2) O-(2-methoxy-2-propyl)hydroxylamine, ${ }^{[47]}$ and 3) Amberlyst 15 ion-exchange resin in methanol furnished the hydroxamates $\mathbf{1} \mathbf{a}-\mathbf{n}$ (from $\mathbf{6}$ ) or $\mathbf{3} \mathbf{a}-\mathbf{o}$ (from $\mathbf{8}$ ). Alternative treatment of $\mathbf{6 a - 1}$ or $\mathbf{8}$ a-o with benzotriazole-1-yloxytris(dimethylamino)phosphonium hexafluorophosphate (BOP reagent), triethylamine and 1,2-phenylendiamine afforded the corresponding 2-aminoanilides $\mathbf{2} \mathbf{a}-\mathbf{I}$ or $\mathbf{4 a - 0}$, respectively (Scheme 1).

Compound $1 \mathrm{a}$ was previously described by us. ${ }^{[43]}$ Chemical and physical data of the tested compounds 1-4 (except $1 \mathrm{a}$ ) and the intermediates 5-8 (except $\mathbf{5} \mathbf{a}$ and $\mathbf{6} \mathbf{a}$ ) as well as ele- mental analyses are reported in tables S1-S3 in the Supporting Information.

\section{Biological assays \\ Maize HD1-B and HD1-A inhibition}

Compounds 1-4 were tested against partially purified maize HD1-B and HD1-A, two homologues of class I and class II HDACs, respectively. However, in Table 1 only the results for compounds $\mathbf{1}$ and $\mathbf{3}$ are presented because the maize enzymes are not sensitive to non-hydroxamate $\mathrm{HDACi}$ up to $250 \mu \mathrm{m}$. $I C_{50}$ values demonstrate that in the 1 series the highest HD1-B inhibitory activity was achieved by inserting a small alkyl group (methyl, ethyl, cyclopropyl), or its isostere (methoxy), at the methylene of the phenylacetyl portion, whereas the derivatives with bigger substituents at this position (that is, isopropyl, allyl, phenyl, benzyl) were less active. In contrast, when testing with HD1-A all substituents used had an inhibitory effect, with the exception of the methoxy and the cyclopropyl (1,1- as well as 1,2-disubstituted) groups, that caused a decrease in HD1-A inhibitory activity of the corresponding derivatives $\mathbf{1 d}, \mathbf{1} \mathrm{m}$, and $\mathbf{1} \mathrm{n}$.

With regard to the arylmethylaminocinnamyl hydroxamates $\mathbf{3}$, the first member of the series (the 3-(4-(benzylamino)phenyl)$\mathrm{N}$-hydroxyacrylamide $\mathbf{3}$ a) displayed high inhibitory activity against HD1-B and fivefold lower potency against HD1-A $\left(\mathrm{IC}_{50}{ }^{\mathrm{HD} 1-\mathrm{B}}=0.020 \mu \mathrm{M} ; \quad \mathrm{IC}_{50}{ }^{\mathrm{HD} 1-\mathrm{A}}=\right.$ $0.102 \mu \mathrm{M})$. Among the (hetero)mono- and bicyclic rings replacing the benzene at the $R^{1}$ position in $\mathbf{3} \mathbf{a}$, only the 2-thienyl, 3 thienyl, 2-naphthyl, and 2-benzofuryl rings assured a similar inhibitory potency against HD1-B, the other being detrimental for enzyme inhibition to varying degrees. In the anti-HD1-A assay, in addition to the chemical replacements that were important for HD1-B inhibition, the substitution of the $\mathbf{3} \mathbf{a}$ benzene ring with the 2-pyridyl, 1-naphthyl, 3-benzothienyl, 2- and 3-quinolinyl rings increased up to fivefold the HD1-A inhibitory activity of the compounds.

The trend of structure-activity relationship (SAR) observed with 


\begin{tabular}{|c|c|c|}
\hline \multirow[t]{2}{*}{ Compd } & \multicolumn{2}{|c|}{$\mathrm{IC}_{50} \pm \mathrm{SD}[\mu \mathrm{M}]$} \\
\hline & HD1-B & HD1-A \\
\hline $1 \mathrm{a}$ & $0.092 \pm 0.003$ & $0.072 \pm 0.004$ \\
\hline $1 \mathrm{~b}$ & $0.072 \pm 0.003$ & $0.080 \pm 0.003$ \\
\hline $1 \mathrm{c}$ & $0.089 \pm 0.004$ & $0.064 \pm 0.002$ \\
\hline $1 \mathrm{~d}$ & $0.083 \pm 0.003$ & $0.140 \pm 0.007$ \\
\hline $1 \mathrm{e}$ & $0.187 \pm 0.006$ & $0.057 \pm 0.002$ \\
\hline $1 \mathrm{f}$ & $0.126 \pm 0.005$ & $0.057 \pm 0.003$ \\
\hline $1 \mathrm{~g}$ & $0.162 \pm 0.006$ & $0.055 \pm 0.003$ \\
\hline $1 \mathrm{~h}$ & $0.133 \pm 0.004$ & $0.074 \pm 0.003$ \\
\hline $1 \mathrm{i}$ & $0.011 \pm 0.0005$ & $0.015 \pm 0.001$ \\
\hline $1 \mathrm{j}$ & $0.032 \pm 0.001$ & $0.056 \pm 0.003$ \\
\hline $1 \mathrm{k}$ & $0.058 \pm 0.002$ & $0.042 \pm 0.001$ \\
\hline 11 & $0.062 \pm 0.002$ & $0.069 \pm 0.003$ \\
\hline $1 \mathrm{~m}$ & $0.065 \pm 0.002$ & $0.196 \pm 0.010$ \\
\hline $1 n$ & $0.064 \pm 0.003$ & $0.132 \pm 0.005$ \\
\hline $3 a$ & $0.020 \pm 0.001$ & $0.102 \pm 0.003$ \\
\hline $3 b$ & $0.058 \pm 0.002$ & $0.154 \pm 0.005$ \\
\hline $3 c$ & $0.690 \pm 0.021$ & $0.160 \pm 0.005$ \\
\hline $3 d$ & $0.150 \pm 0.007$ & $0.112 \pm 0.003$ \\
\hline $3 e$ & $0.025 \pm 0.001$ & $0.059 \pm 0.002$ \\
\hline $3 \mathrm{f}$ & $0.027 \pm 0.001$ & $0.072 \pm 0.004$ \\
\hline $3 \mathbf{g}$ & $0.124 \pm 0.005$ & $0.045 \pm 0.002$ \\
\hline $3 \mathrm{~h}$ & $0.102 \pm 0.005$ & $0.098 \pm 0.004$ \\
\hline $3 i$ & $0.046 \pm 0.002$ & $0.022 \pm 0.001$ \\
\hline $3 \mathbf{j}$ & $0.026 \pm 0.002$ & $0.020 \pm 0.001$ \\
\hline $3 k$ & $0.031 \pm 0.001$ & $0.020 \pm 0.001$ \\
\hline 31 & $0.700 \pm 0.035$ & $0.900 \pm 0.054$ \\
\hline $3 m$ & $0.042 \pm 0.001$ & $0.037 \pm 0.002$ \\
\hline $3 n$ & $0.118 \pm 0.006$ & $0.069 \pm 0.003$ \\
\hline 30 & $0.127 \pm 0.005$ & $0.070 \pm 0.004$ \\
\hline SAHA & $0.028 \pm 0.001$ & $0.180 \pm 0.009$ \\
\hline HDAC42 & $0.009 \pm 0.0005$ & $0.006 \pm 0.0003$ \\
\hline
\end{tabular}

[a] Values represent the mean of at least three separate experiments.

1 and 3 confirmed some of our previous findings suggesting that the requirements for a HDACi to inhibit maize HD1-B are more stringent than those for inhibition of HD1-A: HD1-A has a larger catalytic tunnel than HD1-B, so it can more easily accommodate a wider variety of chemically different compounds. ${ }^{[40]}$

\section{Human recombinant HDAC1 and HDAC4 assays}

The $\mathrm{N}$-hydroxy-3-(4-(2-arylacetamido)phenyl)acrylamides 1 a-l and their $\mathrm{N}$-(2-aminophenyl) counterparts $\mathbf{2} \mathbf{a}-\mathbf{l}$, as well as the $\mathrm{N}$-hydroxy- and N-(2-aminophenyl)-3-(4-(arylmethylamino)phenyl) acrylamides $\mathbf{3} \mathbf{a}-\mathbf{0}$ and $\mathbf{4} \mathbf{a}-\mathbf{0}$, respectively, were tested at $5 \mu \mathrm{m}$ against human recombinant (hr) HDAC1 and HDAC4, using the histone $\mathrm{H} 3$ (HDAC1) or the non-histone trifluoroacetyl-lysine ${ }^{[48]}$ (HDAC4) as a substrate, respectively. The data in Table 2 shows the inhibitory activities of the tested acylaminocinnamyl hydroxamates $\mathbf{1}$ and 2-aminoanilides $\mathbf{2}$ against hrHDAC1 and hrHDAC4. From these results, it is clear that the insertion of a substituent at the methylene portion of the phenylacetylamino moiety in the hydroxamate prototype $\mathbf{1}$ a did not increase the inhibitory potency against HDAC1. In contrast, the replacement of the phenyl ring at the $\mathrm{R}$ position with the bulkier 1- or 2-naphthyl group (compounds $\mathbf{1} \mathbf{i}-\mathbf{I}$ ) led to a clear

\begin{tabular}{|c|c|c|}
\hline \multirow[t]{2}{*}{ Compd } & \multicolumn{2}{|c|}{ Inhibition at $5 \mu \mathrm{M}[\%]$} \\
\hline & hrHDAC1 & hrHDAC4 \\
\hline $1 \mathrm{a}$ & 59.8 & 28.9 \\
\hline $1 \mathrm{~b}$ & 54.6 & 45.0 \\
\hline 1c & 44.5 & 42.4 \\
\hline $1 \mathrm{~d}$ & 66.6 & 72.4 \\
\hline $1 \mathrm{e}$ & 37.5 & 41.6 \\
\hline $1 \mathrm{f}$ & 41.2 & 11.9 \\
\hline $1 \mathrm{~g}$ & 55.3 & 15.3 \\
\hline $1 \mathrm{~h}$ & 54.7 & 14.9 \\
\hline $1 \mathrm{i}$ & 76.2 & 14.0 \\
\hline $1 \mathrm{j}$ & 72.7 & 55.3 \\
\hline $1 \mathrm{k}$ & 75.4 & 38.9 \\
\hline 11 & 66.9 & 42.4 \\
\hline $2 \mathrm{a}$ & 28.6 & 25.5 \\
\hline $2 \mathrm{~b}$ & 71.3 & 0 \\
\hline $2 c$ & 56.2 & 47.6 \\
\hline $2 \mathrm{~d}$ & 72.0 & 38.0 \\
\hline $2 \mathrm{e}$ & 73.2 & 16.2 \\
\hline $2 \mathrm{f}$ & 56.3 & 60.4 \\
\hline $2 \mathrm{~g}$ & 25.8 & 70.0 \\
\hline $2 \mathrm{~h}$ & 42.9 & 50.4 \\
\hline $2 \mathbf{i}$ & 59.2 & 25.3 \\
\hline $2 j$ & 58.3 & 6.2 \\
\hline $2 \mathrm{k}$ & 76.7 & 23.4 \\
\hline 21 & 72.7 & 25.2 \\
\hline HDAC42 & 94.0 & 27.2 \\
\hline SAHA & 93.1 & 63.2 \\
\hline MS-275 & 83.4 & 14.6 \\
\hline
\end{tabular}

improvement in HDAC1 inhibitory activity. In the 2-aminoanilide series (compounds 2), the introduction of a substituent (particularly a methyl, methoxy, or isopropyl group) at the phenylacetyl portion elicited high HDAC1 inhibitory activity. As observed for the hydroxamate counterparts, the replacement at the $\mathrm{R}$ position of the benzene ring of $\mathbf{2} \mathrm{a}$ with the 1- or 2-naphthyl rings (compounds $\mathbf{2} \mathbf{i}-\mathbf{I}$ ) improved the inhibitory capability of the compounds.

With respect to HDAC4 inhibition, in general, the introduction of a small (up to the isopropyl) substituent at the methylene connecting the phenyl to the carbonyl group in $1 \mathrm{a}$ improved the potency of the derivatives. The replacement of the benzene ring of $\mathbf{1}$ a with the naphthyl moiety (compounds $\mathbf{1} \mathbf{i}-$ I) typically furnished an increase in HDAC4 inhibitory potency, with the exception of compound $\mathbf{1} \mathbf{i}$, which showed lower activity. With regard to the 2-aminoanilides 2 , the introduction of large, unsaturated substituents such as the allyl, phenyl, or benzyl groups (see compounds $\mathbf{2} \mathbf{f}-\mathbf{h}$ ) led to an increase in the anti-HDAC4 potency, whereas the phenyl $\rightarrow$ naphthyl replacement was only tolerated $(\mathbf{2} \mathbf{i}, \mathbf{k}, \mathbf{l})$ or detrimental $(\mathbf{2} \mathbf{j})$.

As with the insertion of a substituent at the methylene position of the phenylacetyl moiety of $\mathbf{1} \mathbf{a}$ and $\mathbf{2} \mathbf{a}$ a chiral center was generated, we checked if, in these two series of $\mathrm{HDACi}$, there is stereoselectivity of action. Single enantiomers of hydroxamates $\mathbf{1} \mathbf{b}$ and $\mathbf{1} \mathbf{c}$, as well as the 2 -aminoanilide $\mathbf{2 c}$ were obtained by enantioselective HPLC of racemic forms on the amylose-based Chiralpak IA chiral stationary phases (CSP) 
using normal phase conditions (see table S4 in the Supporting Information). The absolute configuration assignment was accomplished by a combined strategy based on chemical correlation/chiral HPLC/circular dichroism (CD) methods. The $R$ and $S$ enantiomers of 2-phenylbutyric acid were used as chiral synthons to obtain non-racemic forms $(>62 \% e e)$ of $1 \mathrm{c}$ and $2 \mathrm{c}$. The synthesis occurred in stereoconservative way and the final products maintained the original absolute configuration of the starting material. Enantioselective HPLC analysis of racemic samples spiked with the optically active forms of the known absolute configuration allowed the stereochemical characterization of $\mathbf{1} \mathbf{c}$ and $\mathbf{2} \mathbf{c}$. The stereochemistry of $\mathbf{1} \mathbf{b}$ was empirically determined by comparing its $C D$ spectra with those of the structural analogue 1c (see figure S1 in the Supporting Information).

The enantiomers of $\mathbf{1} \mathbf{b}, \mathbf{1} \mathbf{c}$, and $\mathbf{2} \mathbf{c}$, separated on a semipreparative scale, were tested against maize HD1-B and HD1$A$, as well as against hrHDAC1 and hrHDAC4, in comparison with their corresponding racemates. The inhibitory data obtained are summarized in Table 3 . In general, we can observe that the $R$ enantiomer was slightly more active than the $S$

\begin{tabular}{|c|c|c|c|c|}
\hline \multirow[t]{2}{*}{ Compd } & \multicolumn{2}{|c|}{$\mathrm{IC}_{50} \pm \mathrm{SD}[\mu \mathrm{M}]$} & \multicolumn{2}{|c|}{ Inhibition at $5 \mu \mathrm{M}[\%]$} \\
\hline & HD1-B & HD1-A & hrHDAC1 & hrHDAC4 \\
\hline $1 \mathrm{~b}$ & $0.072 \pm 0.003$ & $0.080 \pm 0.003$ & 54.6 & 45.0 \\
\hline (S)-1 b & $0.170 \pm 0.007$ & $0.125 \pm 0.006$ & 45.2 & 33.3 \\
\hline$(R)-\mathbf{1} \mathbf{b}$ & $0.056 \pm 0.002$ & $0.073 \pm 0.004$ & 59.0 & 51.1 \\
\hline $1 \mathrm{c}$ & $0.089 \pm 0.004$ & $0.064 \pm 0.002$ & 44.5 & 42.4 \\
\hline (S)-1 c & $0.101 \pm 0.003$ & $0.063 \pm 0.003$ & 29.5 & 39.2 \\
\hline$(R)-1 \mathrm{c}$ & $0.040 \pm 0.002$ & $0.070 \pm 0.003$ & 49.8 & 49.2 \\
\hline $2 c$ & - & - & 56.2 & 47.6 \\
\hline$(S)-2 c$ & - & - & 52.6 & 26.7 \\
\hline$(R)-2 \mathrm{c}$ & - & - & 78.9 & 48.3 \\
\hline
\end{tabular}

enantiomer. For example, $(R)-\mathbf{1} \mathbf{b}$ was threefold more potent than (S)-1 b as a maize HD1-B inhibitor. In the case of $\mathbf{1} \mathbf{c}$, against the maize HD1-A enzyme there was not a large difference in action between the enantiomers. Concerning the 2aminoanilide $\mathbf{2 c}$, the $R$ enantiomer showed an appreciable improvement in activity with respect to the racemic form against HDAC1 but not against HDAC4.

The inhibitory data for the arylmethylaminocinnamyl hydroxamates (3) and -2-aminoanilides (4) against hrHDAC1 and hrHDAC4 are reported in Table 4 . In the case of the hydroxamates $\mathbf{3}$, the phenylmethylamino prototype $\mathbf{3}$ a displayed $55.6 \%$ inhibition of HDAC1 at $5 \mu \mathrm{M}$, and the replacement of the phenyl ring with the 2- or 3-thienyl (compounds $\mathbf{3 e}$ or $\mathbf{3} \mathbf{f}$ ) as well as a 2-naphthyl or 2-benzofuryl moiety (compounds $\mathbf{3} \mathbf{j}$ or $\mathbf{3} \mathbf{k})$ greatly improved this inhibitory action.

In the corresponding 2-aminoanilide series (compounds 4), the phenyl $\rightarrow$ thienyl replacement led to less potent compounds (see $\mathbf{4 e}$ and $\mathbf{4} \mathbf{f}$ versus $\mathbf{4 a}$ ). However, in this 2 -aminoanilide series this activity was promptly restored by replacing

\begin{tabular}{|c|c|c|}
\hline \multirow[t]{2}{*}{ Compd } & \multicolumn{2}{|c|}{ Inhibition at $5 \mu \mathrm{M}[\%]$} \\
\hline & hrHDAC1 & hrHDAC4 \\
\hline $3 \mathbf{a}$ & 55.6 & 37.5 \\
\hline $3 \mathrm{~b}$ & 34.6 & 29.1 \\
\hline $3 c$ & 31.9 & 0 \\
\hline $3 d$ & 48.1 & 0 \\
\hline $3 e$ & 91.5 & 35.2 \\
\hline $3 \mathrm{f}$ & 91.5 & 11.1 \\
\hline $3 \mathrm{~g}$ & 60.6 & 0 \\
\hline $3 \mathrm{~h}$ & 60.1 & 30.9 \\
\hline $3 i$ & 45.5 & 49.6 \\
\hline $3 \mathbf{j}$ & 94.4 & 22.3 \\
\hline $3 k$ & 74.2 & 0 \\
\hline 31 & 26.0 & 0 \\
\hline $3 \mathrm{~m}$ & 69.9 & 0 \\
\hline $3 \mathbf{n}$ & 64.9 & 0 \\
\hline 30 & 52.0 & 0 \\
\hline $4 a$ & 69.4 & 0 \\
\hline $4 \mathrm{~b}$ & 42.5 & 0 \\
\hline $4 c$ & 67.7 & 31.9 \\
\hline $4 d$ & 36.7 & 27.3 \\
\hline $4 e$ & 38.5 & 22.9 \\
\hline $4 f$ & 44.4 & 32.4 \\
\hline $4 \mathrm{~g}$ & 73.2 & 41.0 \\
\hline $4 \mathrm{~h}$ & 52.3 & 41.9 \\
\hline $4 i$ & 37.5 & 0 \\
\hline $4 j$ & 51.8 & 0 \\
\hline $4 \mathrm{k}$ & 58.3 & 0 \\
\hline 41 & 45.3 & 0 \\
\hline $4 \mathrm{~m}$ & 50.6 & 20.0 \\
\hline $4 n$ & 59.0 & 19.7 \\
\hline 40 & 74.0 & 3.5 \\
\hline SAHA & 93.1 & 63.2 \\
\hline MS-275 & 83.4 & 14.6 \\
\hline
\end{tabular}

the thienyl ring ( $\mathrm{R}^{1}$ position) with the 2-pyridyl (compound $\mathbf{4} \mathbf{g}$ ) or 3-quinolinyl (compound 4o), and to a lesser extent with other related mono- or bicyclic rings (see for examples $\mathbf{4 h}, \mathbf{4 n}$, and $4 \mathbf{k}$ ). Against HDAC4, the majority of the tested compounds of series $\mathbf{3}$ and $\mathbf{4}$ displayed low or no inhibitory activity.

$\mathrm{IC}_{50}$ values against HDAC1, HDAC4, and HDAC6 were determined for selected derivatives of series 1-4 (Table 5). Among them, $1 \mathbf{k}$ was $65-$ and 41 -fold more potent in inhibiting HDAC1 than HDAC4 or HDAC6, respectively, whereas $\mathbf{3} \mathbf{f}$ and $\mathbf{3} \mathbf{g}$, as well as the anilide $\mathbf{2} \mathbf{c}$, behaved as HDAC1/HDAC6-selective inhibitors with low (if any) activity against HDAC4. Finally, the anilides $\mathbf{4 o}$ and, to a lesser extent, $\mathbf{4 n}$ showed privileged HDAC1 inhibition.

\section{Molecular modeling and docking studies}

From the data reported in Table 5, six representative compounds from series 1-4 acted selectively against HDAC1, being 30 to 1000 times more potent against HDAC1 than against HDAC4. To gain insight into HDAC1 selectivity, the binding modes of $\mathbf{1} \mathbf{k}, \mathbf{2 c}, \mathbf{3} \mathbf{f}, \mathbf{3 g}, \mathbf{4} \mathbf{n}$, and $\mathbf{4 o}$ were analyzed in both human HDAC1 (modeled from HDAC2 co-crystallized with $\mathrm{N}$ - 


\begin{tabular}{|c|c|c|c|}
\hline \multirow[t]{2}{*}{ Compd } & \multicolumn{3}{|c|}{$\mathrm{IC}_{50} \pm \mathrm{SD}[\mu \mathrm{M}]$} \\
\hline & HDAC1 & HDAC4 & HDAC6 \\
\hline $1 \mathrm{k}$ & $0.07 \pm 0.01$ & $4.55 \pm 0.27$ & $2.9 \pm 0.12$ \\
\hline $2 c$ & $2.0 \pm 0.1$ & $54.4 \pm 3.6$ & $5.3 \pm 0.21$ \\
\hline $3 \mathrm{f}$ & $0.08 \pm 0.004$ & $78.3 \pm 4.7$ & $0.27 \pm 0.02$ \\
\hline $3 \mathrm{~g}$ & $0.31 \pm 0.01$ & $48.8 \pm 2.44$ & $0.15 \pm 0.01$ \\
\hline $4 n$ & $0.59 \pm 0.02$ & $86.6 \pm 4.33$ & $8.17 \pm 0.49$ \\
\hline 40 & $1.38 \pm 0.05$ & $71.8 \pm 3.6$ & $102.7 \pm 5.13$ \\
\hline
\end{tabular}

[a] Values represent the mean of at least three separate experiments.

(4-aminobiphenyl-3-yl)benzamide, ${ }^{[49]}$ PDB ID: 3MAX) and human HDAC4 ${ }^{[50]}$ (PDB IDs: 2VQJ and 2VQM) using AutoDock 4.2. At first glance, both the hydroxamate $(\mathbf{1} \mathbf{k}, \mathbf{3} \mathbf{f}$, and $\mathbf{3} \mathbf{g})$ and 2-aminoanilide ( $\mathbf{2}$ [both enantiomers], $\mathbf{4} \mathrm{n}$, and $\mathbf{4 0}$ ) representative derivatives in the modeled HDAC1 showed interactions and binding conformations similar to those of the reference experimental bound compounds (TSA, taken from the HDAC8 co-complex, PDB ID: 1T64, and N-(4-aminobiphenyl-3-yl)benzamide from the HDAC2 co-complex, PDB ID: 3MAX; Figure 3). Among the ligand-enzyme interactions, for hydroxamates $(\mathbf{1} \mathbf{k}$, $\mathbf{3} \mathbf{f}$, and $\mathbf{3 g}$ ) the $\mathrm{Zn}^{2+}$ ion chelation is the inhibition driving

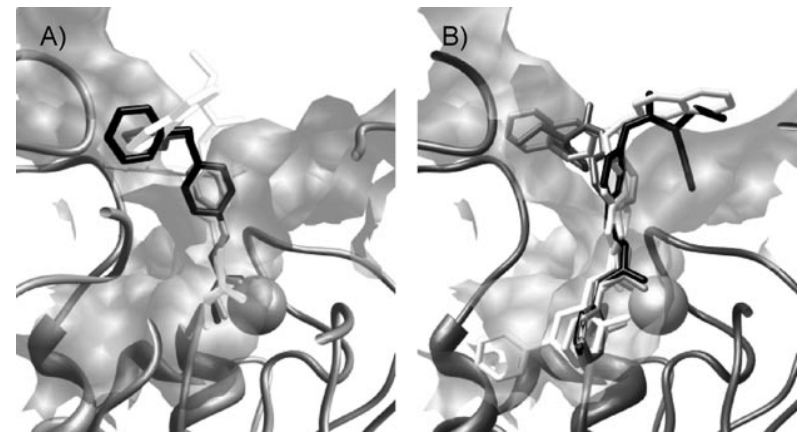

Figure 3. AutoDock-proposed binding modes for the representative A) hydroxamates ( $\mathbf{1} \mathbf{k}$ in white, $\mathbf{3} \mathbf{f}$ in light gray, and $\mathbf{3} \mathbf{g}$ in black) and B) 2-aminoanilides $((S)-2 \mathrm{c}$ in dark gray, $(R)-2 \mathrm{c}$ in black, $4 \mathrm{n}$ in medium gray, and $4 \mathrm{o}$ in light gray). TSA (dark gray) and $\mathrm{N}$-(4-aminobiphenyl-3-yl)benzamide (white) are shown for comparison with the hydroxamate and 2-aminoanilide derivatives, respectively. The gray sphere represents the catalytic $\mathrm{Zn}^{2+}$ ion; also shown in gray is the ribbon representation of HDAC1 (see the color version is available in the Supporting Information).

force, whereas for the weaker zinc chelating 2-aminoanilides (2 c, 4 n, and 4o) further interactions are visible in a pocket formed by His140, Gly149, Cys151, and Gly300 (figure S2 in the Supporting Information), at the beginning of the $14 \AA$ acetate escape tunnel. ${ }^{[51]}$ Nevertheless, other moieties play some roles in the inhibition potency, and in particular all the anilide/aniline ( $C U+$ connected phenyl group) moieties establish $\pi-\pi$ interactions with the HDAC1 s Phe150 and Phe205, while electrostatic interactions are placed between HDAC1-Asp99 and the anilide/aniline nitrogen atom (figure $\mathrm{S} 3$ in the Supporting Information). Regarding the CAP groups, although no interaction seems to be relevant for the inhibition potency, on closer in- spection, the most active derivatives $(\mathbf{1} \mathbf{k}, \mathbf{3} \mathbf{f}, \mathbf{3} \mathbf{g}$, and $\mathbf{4 n}$ ) show that there are two preferred CAP interaction modes: a TSA-like mode, shared by $\mathbf{3} \mathbf{f}$ and $\mathbf{4 n}$, where the dimethylaminophenyl (TSA), the 3-thienyl ( $\mathbf{3} \mathbf{f})$, and the 2-quinolinyl (4n) groups fit into a large cleft paved predominantly by main and side chains of His28, Pro29, Asp99, and Phe150 residues, and a narrow canyon delimited by Asn95, Asp99, Ser148, Gly149, and Phe205 where the $\mathbf{1} \mathbf{k}$ naphthylethylmethyl and the $\mathbf{3} \mathbf{g}$ pyridylmethyl groups fill the available space. On the other hand less active compounds, such as $\mathbf{2 c}$ and $\mathbf{4 o}$, although structurally related, where docked by AutoDock with a different mode, in which the phenylethylmethyl (2c) and the 3-quinolinyl (4o) moieties are lying on a wide, open area bordered by His175, Tyr204, and Leu271 (figure S4 in the Supporting Information).

In contrast to HDAC1, HDAC4 shows a wider substrate binding channel partially deprived of the acetate escape tunnel ${ }^{[51]}$ at the side of the $\mathrm{Zn}^{2+}$ ion. This lack prevents the 2-aminoanilide derivatives from reaching effective chelating distances thus lowering the activity against HDAC4 (figure S5 in the Supporting Information). The wide, open shape of the HDAC4 catalytic tunnel also imparts some disadvantages for the hydroxamate series. The missing $\pi-\pi$ sandwich, observed for HDAC1, prevents the inhibitors from being anchored to the tunnel, and the hydroxamate functions to properly chelate the $\mathrm{Zn}^{2+}$ ion. Similarly, as reported for the co-crystal structure 2VQM (data not shown), ${ }^{[0]}$ only the hydroxamate carbonyl groups showed the required distances to make electrostatic-type interactions with the $\mathrm{Zn}^{2+}$ ion, whereas the hydroxy groups are on the average $5 \AA$ away from the metal ion. Interestingly, among the tested derivatives in Table 5, $\mathbf{1} \mathbf{k}$ displayed the highest activity. A closer inspection of the $1 \mathbf{k}$ AutoDock binding mode revealed that the central amide makes two strong hydrogen bonds with Phe227 and Pro298 (figure S6 in the Supporting Information), that in some way compensates for the lack of full $\mathrm{Zn}^{2+}$ ion chelation.

\section{Effects on acetylation level of histone (histone H3) and non- histone ( $\alpha$-tubulin) substrates. p21 Induction}

As a functional test for HDAC inhibition we performed western blot analyses with specific antibodies using human leukemia U937 cells to determine the effects on the acetylation levels of histone $\mathrm{H} 3$ and $\alpha$-tubulin for compounds $\mathbf{1 - 4}$, tested at $5 \mu \mathrm{M}$ for $24 \mathrm{~h}$. SAHA and MS-275 were used as reference drugs. In these conditions, the acylamino hydroxamates $\mathbf{1}$ as well as most of the related 2-aminoanilides $\mathbf{2}$ (see compounds $\mathbf{2} \mathbf{a}-\mathbf{g}$, $\mathbf{k}$, I) were able to increase the acetylation levels of histone $\mathrm{H} 3$, having a fair correlation with their HDAC1 inhibition activities (Figure 4A). In contrast, only a few hydroxamates from the 1 series ( $\mathbf{1} \mathbf{a}, \mathbf{1} \mathbf{g}$, and $\mathbf{1} \mathbf{h}$ ) and, interestingly, none 2 -aminoanilide from the 2 series induced high acetylation in $\alpha$-tubulin (Figure $4 \mathrm{~B}$ ), suggesting a general low or no inhibitory activity of the above derivatives against HDAC6. Among the arylmethylamino cinnamyl compounds $\mathbf{3}$ and $\mathbf{4}$, the majority of the hydroxamates (3) and, to a lesser extent, the anilides (4) caused an increase in both the acetyl-histone $\mathrm{H} 3$ and acetyl- $\alpha$-tubulin levels, with no difference resulting from the substrate used 
A)
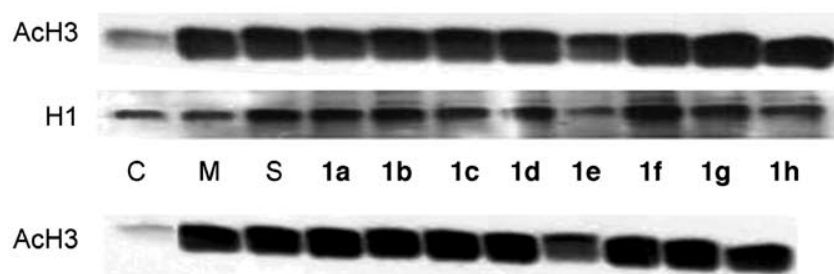

$\mathrm{H1}$
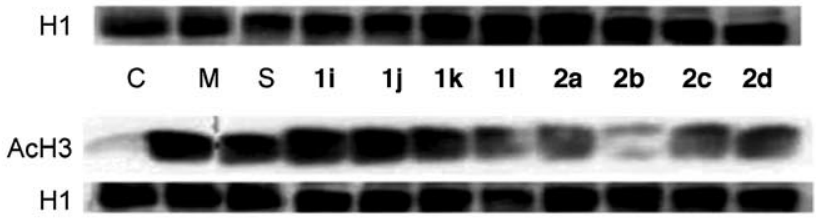

$\begin{array}{lllllllllll}C & M & S & 2 e & 2 f & 2 g & 2 h & 2 i & 2 j & 2 k & 2 l\end{array}$

C)
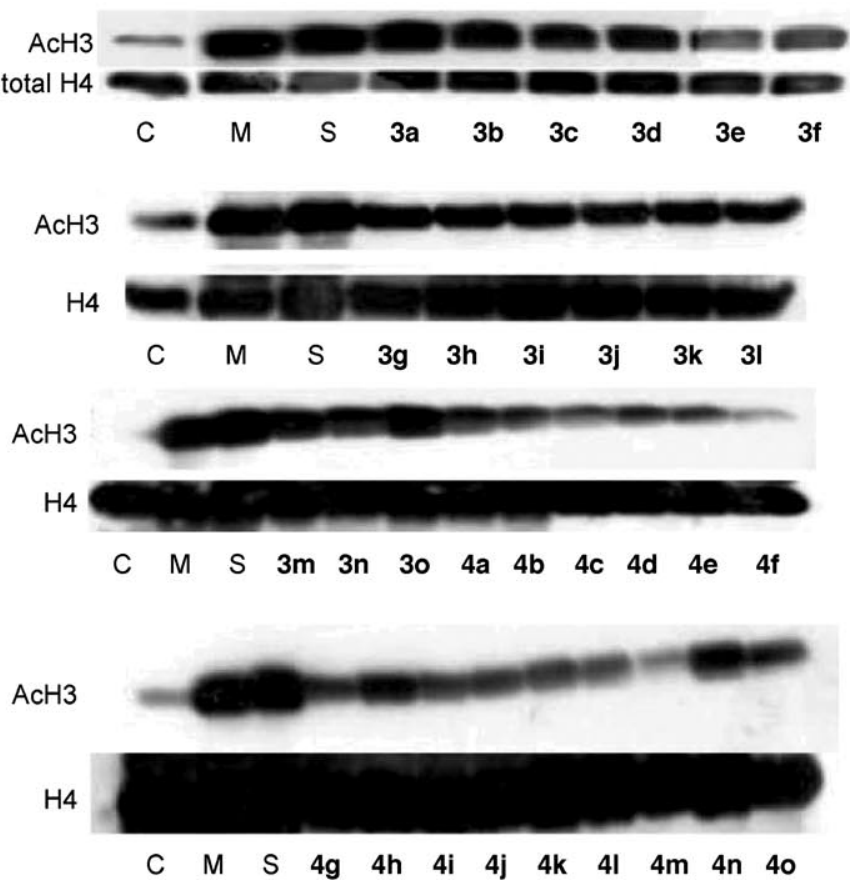

B)

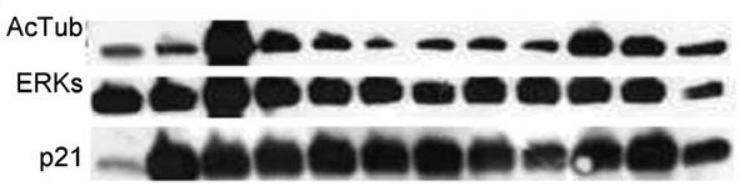

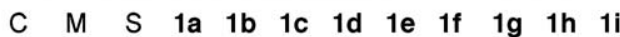

AcTub $\quad \longrightarrow-\infty-\infty$

ERKs

p21

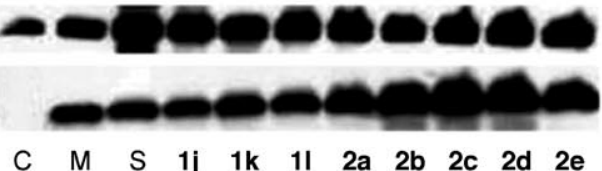

AcTub

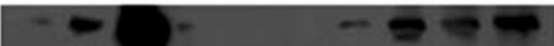

ERKs

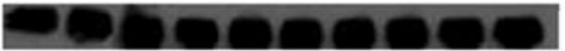

p21

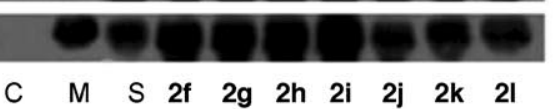

D)
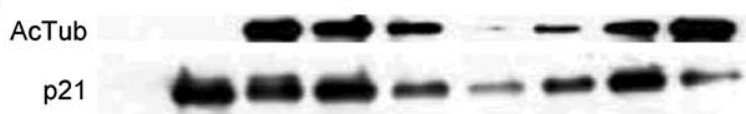

ERKs E

$\begin{array}{lllllllll}C & M & S & 3 a & 3 b & 3 c & 3 d & 3 e & 3 f\end{array}$

AcTub

p21

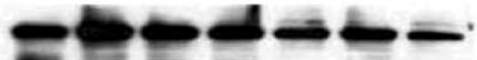

ERKs

$\begin{array}{lllllllll}C & M & S & 3 g & 3 h & 3 \mathbf{i} & 3 \mathbf{j} & 3 \mathbf{k} & 3 \mathbf{l}\end{array}$

AcTub : I : e equer

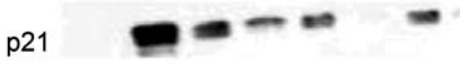

ERKs $\mathrm{COCO}$

C $\quad M \quad S \quad 3 m$ 3n 3o $4 a$ 4b $4 c \quad 4 d \quad 4 e \quad 4 f$

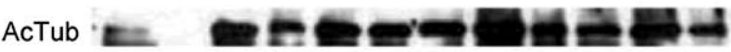

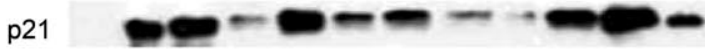

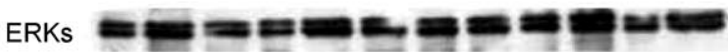

C $\quad M \quad S \quad 4 g \quad 4 h \quad 4 i \quad 4 j \quad 4 k \quad 4 I \quad 4 m \quad 4 n \quad 40$

Figure 4. Effects of compounds 1-4 $(5 \mu \mathrm{M}, 24 \mathrm{~h})$ on acetylation levels of histone $\mathrm{H} 3$ and $\alpha$-tubulin, and on p21 induction in U937 leukemia cells. Western blot analyses were performed with specific antibodies: A) Acetyl-H3 assay with compounds 1 and 2 ; histone $\mathrm{H} 1$ was used for equal loading. B) Acetyl- $\alpha$-tubulin and p21 assays with compounds 1 and 2; ERKs were used for equal loading. C) Acetyl-H3 assay with compounds $\mathbf{3}$ and 4 ; histone $\mathrm{H} 4$ was used for equal loading. D) Acetyl- $\alpha$-tubulin and p21 assays with compounds 3 and 4; ERKs were used for equal loading. Lane abbreviations: $C=$ control, $M=M S-275$, $S=S A H A$.

(Figure $4 \mathrm{C}$ and $4 \mathrm{D}$ ). In some cases ( $\mathbf{3} \mathbf{f}-\mathbf{i}, \mathbf{3} \mathbf{m}-\mathbf{0}$, and $\mathbf{4 k}$ ), an increase in $\alpha$-tubulin acetylation was observed, higher than that obtained with SAHA.

The induction of the cell-cycle inhibitor p21, a typical effect reported mainly for class I HDAC inhibitors, ${ }^{[52,53]}$ was determined for compounds 1-4 using western blot analysis. Figure $4 \mathrm{~B}$ shows that, in general, both the hydroxamates 1 and the 2-aminoanilides 2 induced p21, compounds 2 being in many cases ( $\mathbf{2} \mathbf{b} \mathbf{b}-\mathbf{i})$ more efficient than MS-275 and SAHA in the tested conditions. Conversely, the arylmethylaminocinnamyl hydroxamates 3 showed weak p21 induction, lower than those obtained with the reference drugs, with the exception of $\mathbf{3}$ a and $3 \mathbf{e}$, that gave a high signal. The arylmethylaminocinnamyl anilides 4 were, in general, unable to induce p21 in these conditions, with the remarkable exception of $\mathbf{4 h}, \mathbf{4 m}$, and $\mathbf{4 n}$, that showed a p21 induction level higher than ( $\mathbf{4 h}$ and $\mathbf{4 n}$ ) or similar to $(\mathbf{4} \mathbf{m})$ those obtained with MS-275 and SAHA (Figure 4D). 

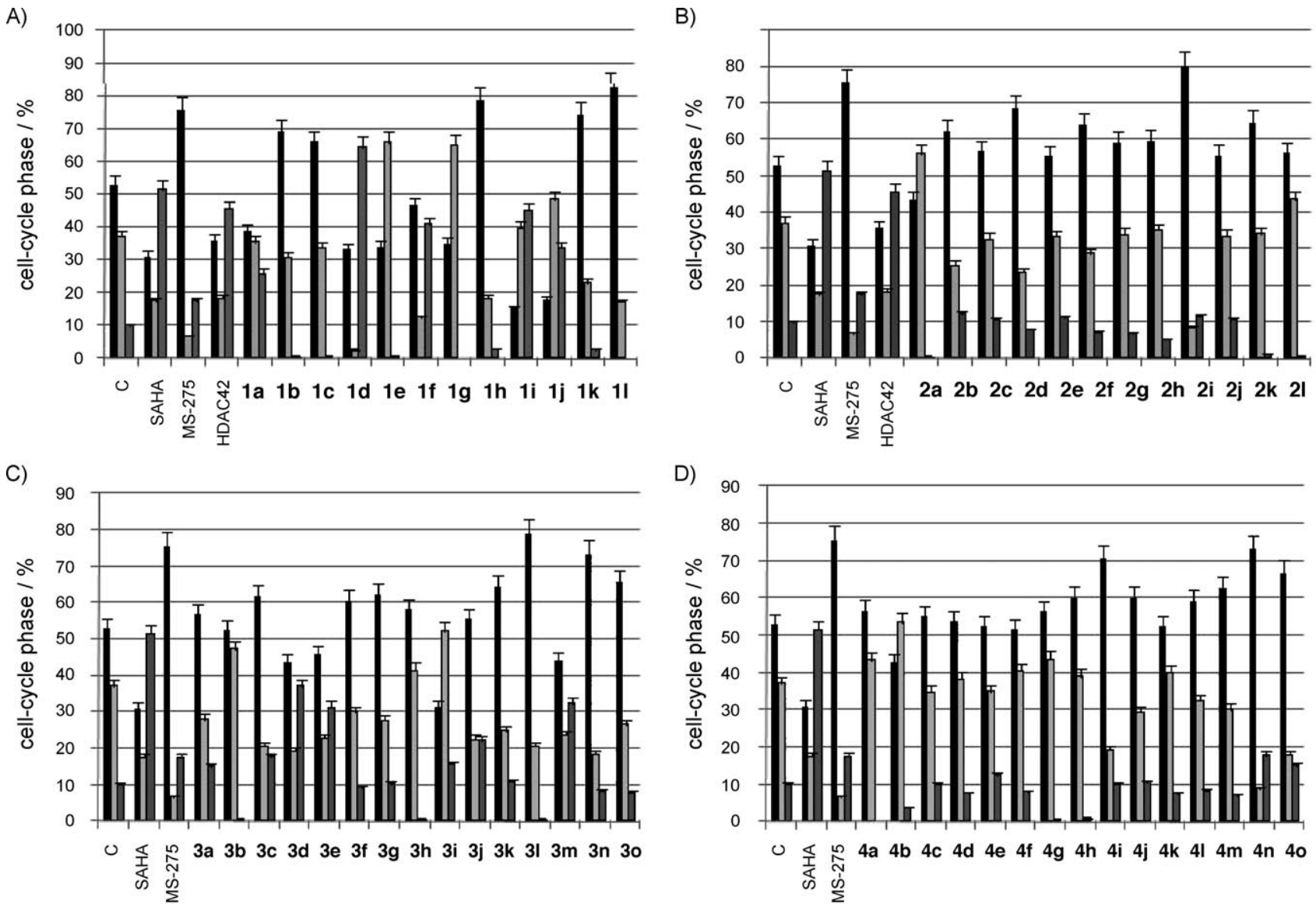

Figure 5. Cell-cycle analysis in U937 leukemia cells treated with compounds 1-4 at $5 \mu \mathrm{M}$ for $30 \mathrm{~h}$ (black columns: $\mathrm{G}_{1}$, light gray: $\mathrm{S}$, medium gray: $\mathrm{G}_{2}$ ).

Cell-cycle analysis, apoptosis induction, granulocytic differentiation, and antiproliferative activity in human U937 leukemia cells

Compounds 1-4 were tested in the human U937 leukemia cell line to determine their effects on cell cycle, apoptosis induction, granulocytic differentiation, and antiproliferative activity. In addition, SAHA, MS-275, and/or HDAC42 were used as reference drugs. All the compounds were tested at $5 \mu \mathrm{M}$ for $30 \mathrm{~h}$. In these conditions, the tested compounds displayed an arrest of the cell cycle of $U 937$ cells either at $G_{2} / M$ or $G_{1} / S$ phase, depending on the general behavior shown by the cancer cells following treatment with HDACi (Figure 5). ${ }^{[54,55]}$ In particular, some of the tested hydroxamates blocked the cell cycle at the $\mathrm{G}_{2} / \mathrm{M}$ phase (including SAHA and HDAC42), whereas others caused cell-cycle arrest at the $G_{1} / S$ phase. The 2 -aminoanilide derivatives $\mathbf{2}$ and 4, as well as MS-275 always blocked the cell cycle at the $G_{1} / S$ phase.

The induction of apoptosis was evaluated by caspase 3-7 activation (Figure 6). After treatment of U937 cells with 1-4 at $5 \mu \mathrm{M}$ for $30 \mathrm{~h}$, some hydroxamates belonging to the 1 series $(\mathbf{1} \mathbf{h}-\mathbf{l})$ yielded the highest percentage of apoptosis, higher than those obtained with SAHA and HDAC42 in this assay. In particular, $\mathbf{1} \mathbf{k}$ and $\mathbf{1} \mathbf{l}$ carrying 2-(1- and 2-naphthyl)butyrylamino moieties as a CAP + CU group, induced high, dose-depen- dent apoptosis more efficiently than SAHA, which was used as a reference drug (Figure 7). The percent of apoptosis obtained with the other compounds active in this test was higher than (see, for example, $\mathbf{2 l}$ and $\mathbf{4} \mathrm{d}$ ) or similar to that observed with SAHA (1 a, $\mathbf{1}$ c, $\mathbf{3}$ a, 3 j, 3l, $\mathbf{3} \mathbf{m}, \mathbf{4 e}, \mathbf{4} \mathrm{f}$, and $\mathbf{4 l}$ ). The benzamide MS-275 showed a modest apoptosis induction (7.7\%) in these experimental conditions.

The hydroxamates $\mathbf{1} \mathbf{k}$ and $\mathbf{1 I}$ as well as the 2-aminoanilides 2c and $4 \mathrm{n}$ were tested at $5 \mu \mathrm{M}$ in U937 cells to evaluate their effects on cell proliferation, using SAHA $(5 \mu \mathrm{M})$ as reference drug. The cells were counted using Trypan Blue dye every $24 \mathrm{~h}$ for three days. Figure 8 clearly shows that $1 \mathbf{k}$ and $1 \mathrm{l}$ and, to a lesser extent, $\mathbf{4 n}$ and $\mathbf{2 c}$ were able to arrest U937 cell proliferation.

The increased expression of the surface antigen CD11c was used as a marker of granulocytic differentiation in U937 leukemia cells. The cells were treated with compounds 1-4 at $5 \mu \mathrm{M}$ for $30 \mathrm{~h}$, and then the percent values of CD11c-positive/propidium iodide (PI)-negative cells were determined (Figure 9). In these conditions, the majority of the 2-aminoanilide derivatives (series 2 and 4 ) showed interesting ( $50 \%$ of $C D 11 \mathrm{c}+/ \mathrm{PI}-$ cells) cytodifferentiation properties, similar to that observed with MS-275. In particular, $\mathbf{2} \mathbf{b}, \mathbf{2} \mathbf{C}, \mathbf{2} \mathbf{e}$, and $\mathbf{2} \mathbf{i}$ (bearing as a CAP + CU a methyl-, ethyl-, and isopropyl substitution at the phenylacetylamino moiety, or a 1-naphthylacetylamino group, 

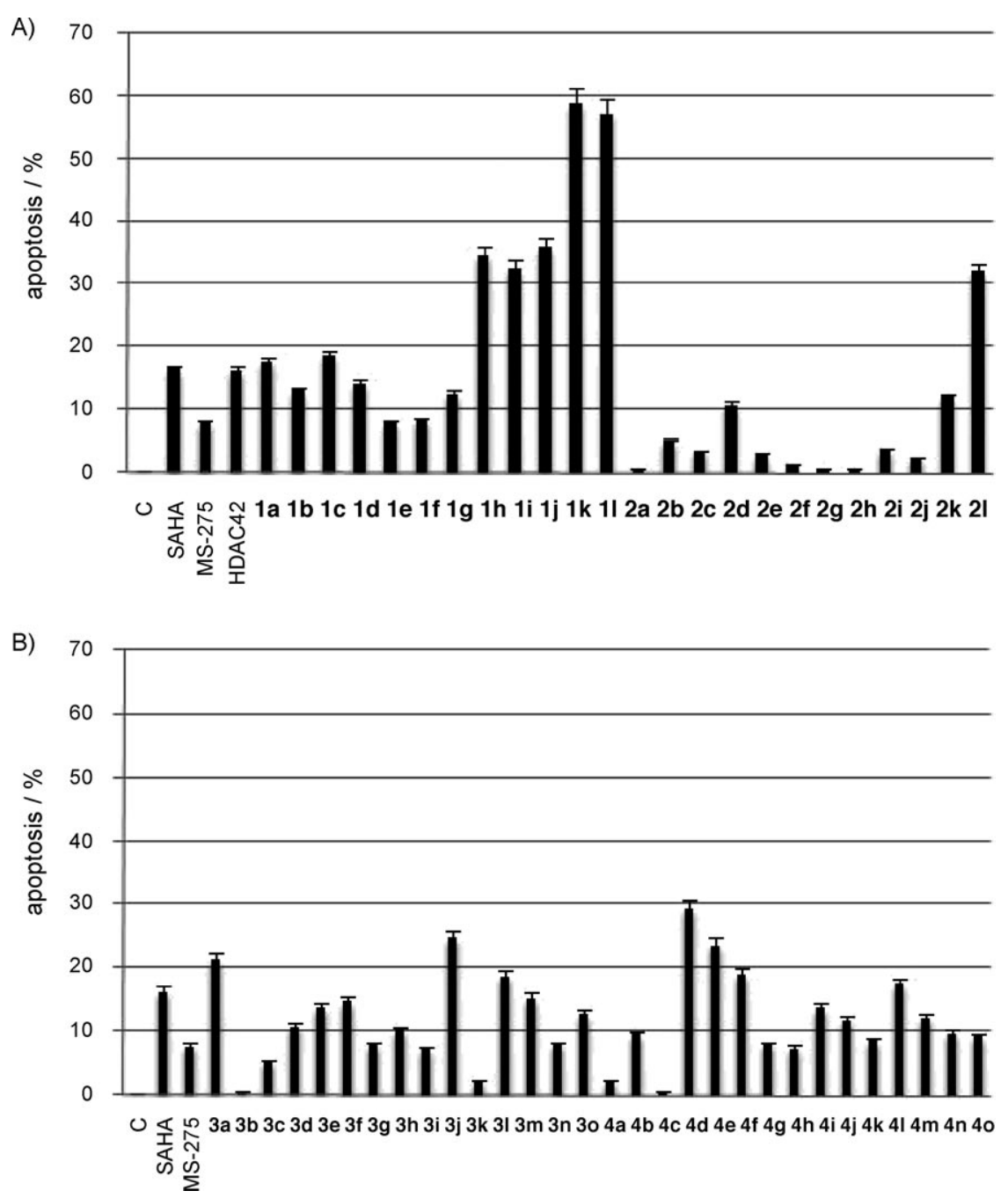

Figure 6. Apoptosis induction in U937 leukemia cells by compounds 1-4, tested at $5 \mu \mathrm{M}$ for $30 \mathrm{~h}$. the top-scoring compounds $2 \mathrm{c}$ and $\mathbf{4 n}$, obtaining dose-dependence differentiation activity from 1 to $5 \mu \mathrm{M}$ (Figure 10), whereas at $25 \mu \mathrm{M}$ a lesser number of $\mathrm{CD} 11 \mathrm{c}+/ \mathrm{PI}-$ cells was registered, probably resulting from cytotoxicity problems (see Figure S7 in Supporting Information). Among the hydroxamates 1 and 3, the majority of those from the $\mathbf{3}$ series furnished a differentiating activity ranging from 30 to $40 \%$ of CD11c + /PI- cells, whereas those from the 1 series were less active. Because of their intense coloration, some compounds could not be tested in the CD11c assay. Thus, they were tested on U937 cells at $5 \mu \mathrm{M}$ for $30 \mathrm{~h}$ by using the Nitro-tetrazolium Blue (NBT) assay, a general test for differentiation of cells. All the tested compounds (3c, $\mathbf{3} \mathbf{j}, \mathbf{3 n}, \mathbf{4} \mathbf{c}, \mathbf{4 i}, \mathbf{4} \mathbf{j}$, and $4 \mathrm{l}$ ) were less efficient than MS-275 at inducing cell differentiation in this test (see Figure S8 in the Supporting Information).

\section{Conclusions}

Four series of HDAC inhibitors bearing the cinnamyl moiety as a hydrophobic spacer (HS) be-

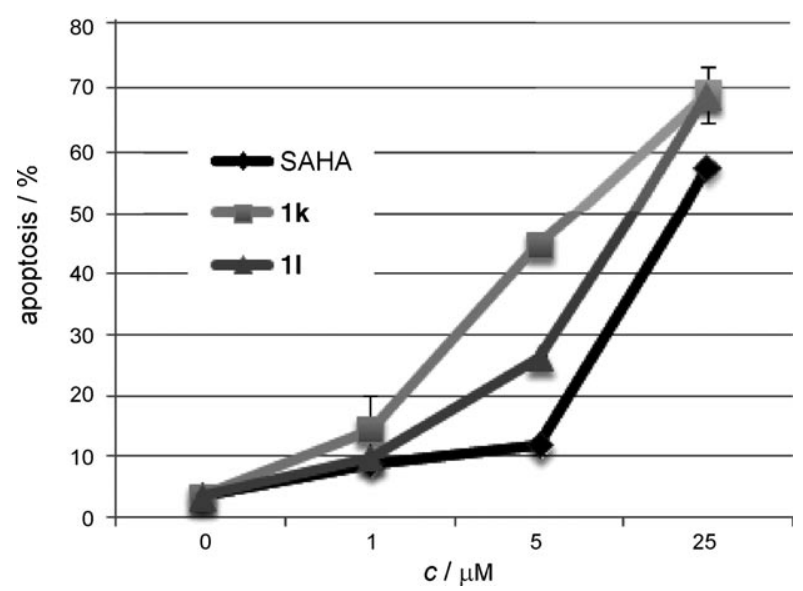

Figure 7. Dose-dependent induction of apoptosis by $1 \mathbf{k}, 1 \mathrm{I}$, and SAHA in U937 cells for $30 \mathrm{~h}$.

respectively), as well as $\mathbf{4 g}, \mathbf{4 h}, \mathbf{4} \mathbf{n}$, and $\mathbf{4 0}$ (showing the 2and 3-pyridyl or the 2- or 3-quinolinyl ring as a CAP, respectively), furnished values of CD11c + /PI- cells similar to or higher than that of MS-275. Dose-response curves were generated for

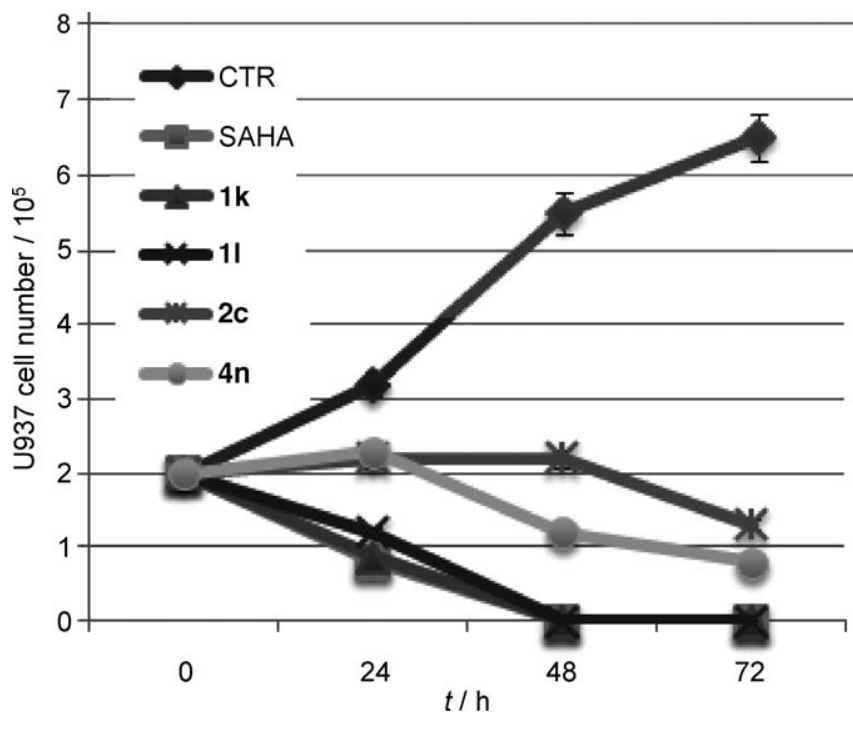

Figure 8. Antiproliferative activity exerted by $\mathbf{1 k}, \mathbf{1}$, $\mathbf{2 c}, \mathbf{4 n}$, and SAHA (all at $5 \mu \mathrm{M}$ ) in U937 leukemia cells. 

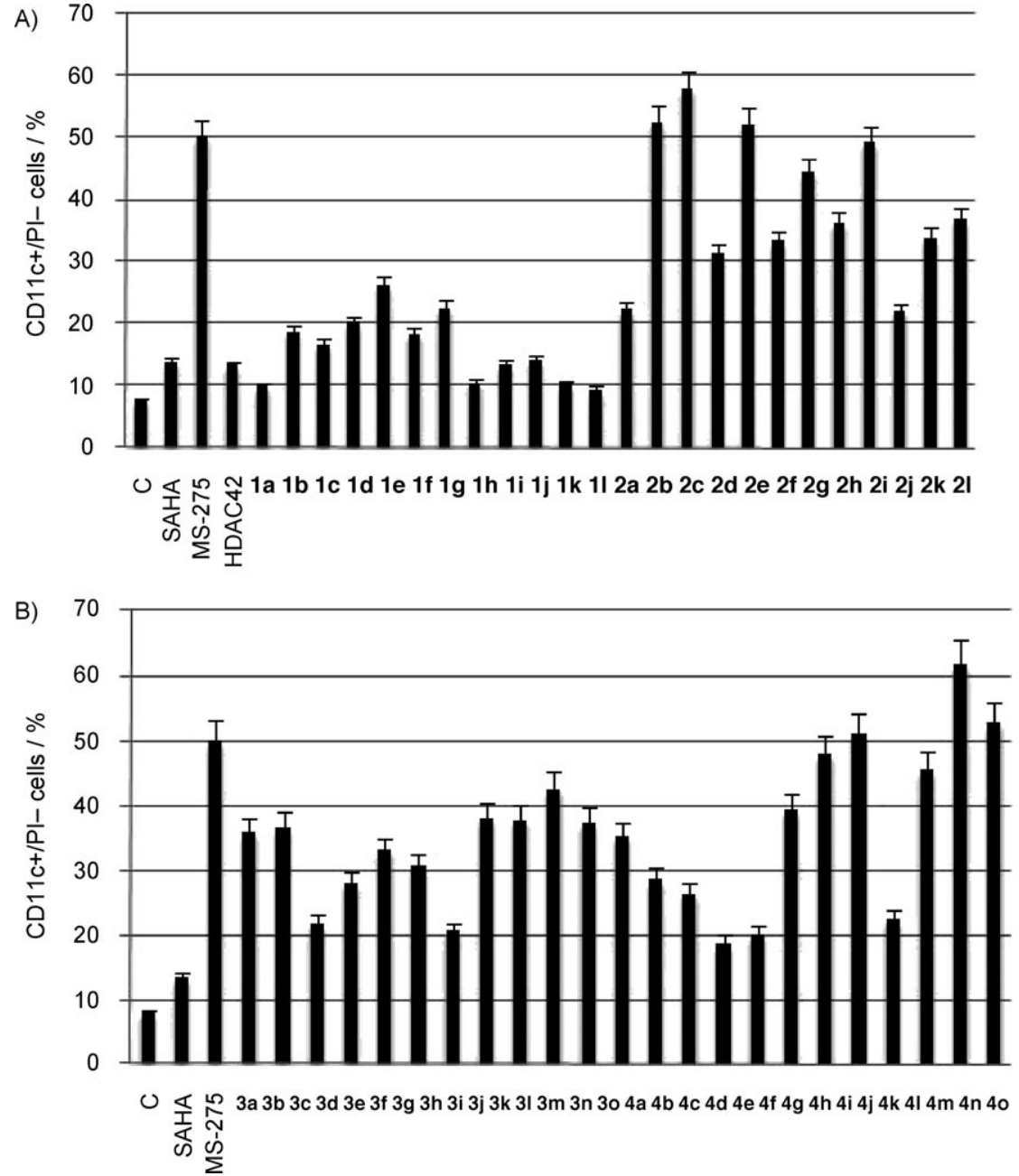

Figure 9. Cytodifferentiation activity (evaluated as a percentage of CD11C $+/ \mathrm{PI}-$ cells) for compounds 1-4 (5 $\mu \mathrm{M}$, $30 \mathrm{~h}$ ) in U937 leukemia cells.

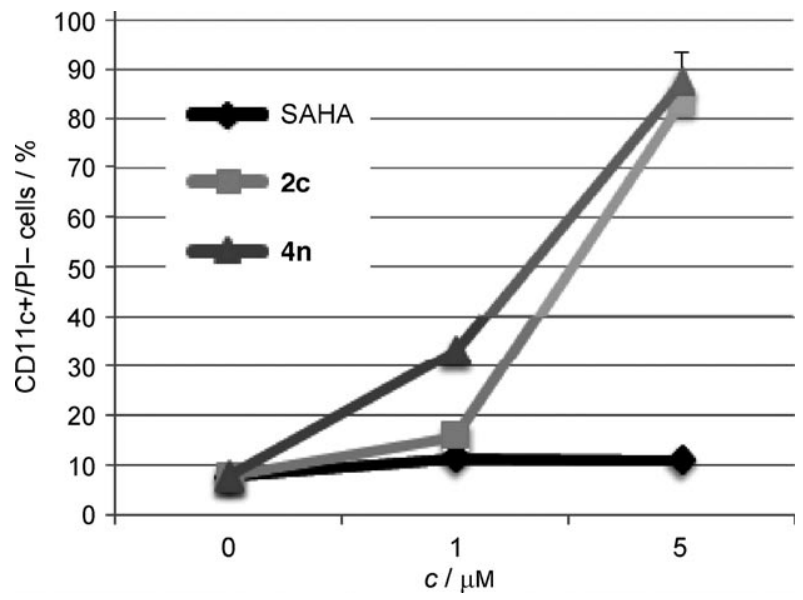

Figure 10. CD11c +/PI- cell expression by $\mathbf{2 c}, \mathbf{4 n}$, and SAHA in U937 cells for $30 \mathrm{~h}$.

tween the CAP + Connection Unit (CU) portion and the zinc binding group (ZBG) are reported herein. As a $C A P+C U$ portion, we used either a substituted arylacetylamino or a arylmethylamino group (compounds $\mathbf{1}$ and $\mathbf{2}$, or $\mathbf{3}$ and $\mathbf{4}$, respective- ly), and as a ZBG we introduced either an hydroxamate or a 2aminoanilide function (compounds 1 and $\mathbf{3}$, or $\mathbf{2}$ and $\mathbf{4}$, respectively). In addition, we prepared SAHA, MS-275, and HDAC42 to use as reference drugs. The novel derivatives were tested in enzyme assays for determining their inhibition capability against maize HD1-B, maize HD1-A, and human recombinant HDAC1 and HDAC4. Unfortunately, the maize system is not sensitive to non-hydroxamate $\mathrm{HDACi}$, thus we reported the inhibitory data only for the hydroxamates $\mathbf{1}$ and $\mathbf{3}$. Nevertheless, a correlation was observed between the inhibitory activities of compounds 1 and 3 in maize and human enzymes, the most potent of them in the maize system (for example, the naphthyl-containing compounds $\mathbf{1} \mathbf{i}-\mathbf{l}$, or the 2- or 3-thienyl- or 2naphthylmethyl derivatives $\mathbf{3 e}$, $\mathbf{3} \mathbf{f}$, and $\mathbf{3} \mathbf{j}$ ) also displayed the highest inhibition against human HDAC1. The 2-aminoanilides belonging to the $\mathbf{2}$ and $\mathbf{4}$ series showed various degrees of HDAC1 and HDAC4 inhibition, with a general HDAC1-selectivity for most of them.

Immunoblotting analyses, which were performed to determine the effects of compounds 1-4 on the acetylation levels of histone $\mathrm{H} 3$ and $\alpha$-tubulin in human U937 leukemia cells, showed a general increase in histone $\mathrm{H} 3$ acetylation, and a failure to increase acetyl- $\alpha$-tubulin levels, with some exceptions observed for $\mathbf{3}$ and $\mathbf{4}$ derivatives. In particular, treatment with $\mathbf{3} \mathbf{f}-\mathbf{i}, \mathbf{3} \mathbf{m}-\mathbf{o}$, and $\mathbf{4} \mathbf{k}$ led to acetyl$\alpha$-tubulin levels higher than SAHA.

Compounds 1-4 were also tested in U937 leukemia cells to study their effects on cell cycle, apoptosis induction, proliferation, and granulocytic differentiation. The majority of the tested compounds were able to arrest the U937 cell cycle either in the $G_{2} / M$ phase, similar to SAHA and HDAC42, or in the $G_{1} / S$ phase, similar to MS-275. Regarding apoptosis induction, five hydroxamates belonging to the $\mathbf{1}$ series $(\mathbf{1} \mathrm{h}-\mathbf{1} \mathrm{I})$ resulted in a higher percent of apoptosis than SAHA and HDAC42, the most potent reference drugs in this assay, $\mathbf{1} \mathbf{k}$ and 1 I showing dose-dependent effects. Selected compounds ( $\mathbf{1} \mathbf{k}$ $\mathbf{1}$, 2 c, and 4n) were able to arrest cell proliferation in U937 cells. In the CD11c cytodifferentiation test, the benzamide MS275 was the most potent of the reference drugs, and some 2 aminoanilides belonging to both the $\mathbf{2}(\mathbf{2} \mathbf{b}, \mathbf{2} \mathbf{c}, \mathbf{2 e}$, and $\mathbf{2} \mathbf{i})$ 
and $4(\mathbf{4 g}, \mathbf{4 h}, \mathbf{4 n}$, and $\mathbf{4 o})$ series furnished the same as or higher activity than MS-275.

The highest-scoring derivatives in terms of apoptosis and antiproliferative activity $(\mathbf{1} \mathbf{k}, \mathbf{1}$ l) or cytodifferentiation $(\mathbf{2}$ c, $\mathbf{4 n}$ ) will be studied further to assess their effects in a panel of cancer cell lines and to investigate their drug-like properties.

\section{Experimental Section}

\section{Chemistry}

Melting points were determined on a Büchi 530 melting point apparatus and are uncorrected. IR spectra $(\mathrm{KBr})$ were recorded on a PerkinElmer Spectrum One instrument. ${ }^{1} \mathrm{H} N \mathrm{NMR}$ spectra were recorded at $400 \mathrm{MHz}$ on a Bruker AC 400 spectrometer; chemical shifts $(\delta)$ are reported in ppm relative to the internal reference $\left(\mathrm{CH}_{3}\right)_{4} \mathrm{Si}$. All compounds were routinely checked by TLC and ${ }^{1} \mathrm{H}$ NMR. TLC was performed on aluminum-backed silica gel plates (Merck DC, Alufolien Kieselgel $60 \mathrm{~F}_{254}$ ) with spots visualized by UV light. All solvents were reagent grade and, when necessary, were purified and dried by standard methods. Concentration of solutions after reactions and extractions involved the use of a rotary evaporator operating at reduced pressure of $\sim 20$ Torr. Organic solutions were dried over anhydrous $\mathrm{Na}_{2} \mathrm{SO}_{4}$. Analytical results are within $\pm 0.40 \%$ of the theoretical values. A SAHA sample for biological assays was prepared as previously reported by us. ${ }^{[56]} \mathrm{MS}$ 275 and HDAC42 were synthesized according to the literature. ${ }^{[57,29]}$ All chemicals were purchased from Aldrich Chimica, Milan (Italy), or from Lancaster Synthesis $\mathrm{GmbH}$, Milan (Italy), and were of the highest purity.

General procedure for the synthesis of ethyl 3-(4-acylaminophenyl)-2-propenoates $5 \mathrm{a}$-n. Ethyl 3-[4-(2-phenylbutyryl)aminophenyl]-2-propenoate $(5 \mathrm{c})$ : 2-Phenylbutyryl chloride (1.2 equiv, $7.32 \mathrm{mmol}, 1.33 \mathrm{~g}$ ) and $\mathrm{Et}_{3} \mathrm{~N}$ (2.5 equiv, $15.22 \mathrm{mmol}, 2.12 \mathrm{~mL}$ ) were added to a solution of ethyl 3-(4-aminophenyl)-2-propenoate hydrochloride $^{[43]}$ (1.0 equiv, $6.1 \mathrm{mmol}, 1.39 \mathrm{~g}$ ) in dry dichloromethane $(20 \mathrm{~mL})$ at $0^{\circ} \mathrm{C}$. After stirring at RT for $4 \mathrm{~h}$, the reaction mixture was poured into $\mathrm{H}_{2} \mathrm{O}(50 \mathrm{~mL})$, the organic layer was separated, and the aqueous one was extracted with $\mathrm{CHCl}_{3}(2 \times 50 \mathrm{~mL})$. The combined organic solution was washed with $\mathrm{H}_{2} \mathrm{O}(100 \mathrm{~mL})$ and brine $(100 \mathrm{~mL})$, and was dried and evaporated to dryness. The residual solid was purified by crystallization from cyclohexane to yield pure 5c. ${ }^{1} \mathrm{H}$ NMR $\left(\mathrm{CDCl}_{3}\right): \delta=0.91-0.95\left(\mathrm{t}, 3 \mathrm{H}, \mathrm{OCH}_{2} \mathrm{CH}_{3}\right), 1.30-1.34(\mathrm{t}$, $\left.3 \mathrm{H}, \mathrm{PhCHCH}_{2} \mathrm{CH}_{3} \mathrm{CO}\right), 1.98-2.01\left(\mathrm{~m}, 1 \mathrm{H}, \mathrm{PhCHCH}_{2} \mathrm{CH}_{3} \mathrm{CO}\right), 2.20-2.23$ (m, $1 \mathrm{H}, \mathrm{PhCHCH}_{2} \mathrm{CH}_{3} \mathrm{CO}$ ), 3.39-3.41 (m, $\left.1 \mathrm{H}, \mathrm{PhCHCO}\right), 4.22-4.28$ (q, $\left.2 \mathrm{H}, \mathrm{OCH}_{2} \mathrm{CH}_{3}\right), 6.32-6.36(\mathrm{~d}, 1 \mathrm{H}, \mathrm{PhCH}=\mathrm{CHCOOEt}), 7.27-7.49(\mathrm{~m}$, $10 \mathrm{H}$, benzene and $\mathrm{CONHPh}), 7.58-7.62 \mathrm{ppm}(\mathrm{d}, 1 \mathrm{H}, \mathrm{PhCH}=$ CHCOOEt).

General procedure for the synthesis of 3-(4-acylaminophenyl)-2propenoic acids $6 \mathrm{a}-\mathrm{n}$. 3-[4-(2-Phenylbutyryl)aminophenyl]-2-propenoic acid (6c): A mixture of $5 \mathrm{c}(1.0$ equiv, $0.65 \mathrm{mmol} 0.20 \mathrm{~g})$, $\mathrm{LiOH} \cdot \mathrm{H}_{2} \mathrm{O}$ (2.0 equiv, $1.30 \mathrm{mmol}, 0.054 \mathrm{~g}$ ), and THF $(15 \mathrm{~mL}$ ) was stirred at RT. After $24 \mathrm{~h}, 2 \mathrm{~N} \mathrm{HCl}$ was added to the mixture to give $\mathrm{pH} 5$, and the obtained solid was filtered and recrystallized to yield pure $6 \mathrm{c}$. ${ }^{1} \mathrm{H}$ NMR ( $\left.\left[\mathrm{D}_{6}\right] \mathrm{DMSO}\right): \delta=0.83-0.85\left(\mathrm{t}, 3 \mathrm{H}, \mathrm{PhCHCH}_{2} \mathrm{CH}_{3} \mathrm{CO}\right)$, 1.68-1.71 $\left(\mathrm{m}, 1 \mathrm{H}, \quad \mathrm{PhCHCH}_{2} \mathrm{CH}_{3} \mathrm{CO}\right), 2.05-2.08(\mathrm{~m}, 1 \mathrm{H}$, PhCHCH $\left.\mathrm{CH}_{3} \mathrm{CO}\right), 3.60-3.62(\mathrm{~m}, 1 \mathrm{H}, \mathrm{PhCHCO}), 6.40-6.44(\mathrm{~d}, 1 \mathrm{H}$, $\mathrm{PhCH}=\mathrm{CHCOOH}), 7.21-7.64(\mathrm{~m}, 10 \mathrm{H}$, benzene and $\mathrm{PhCH}=$ $\mathrm{CHCOOH}), 10.43(\mathrm{~s}, 1 \mathrm{H}, \mathrm{COOH}), 12.20 \mathrm{ppm}(\mathrm{s}, 1 \mathrm{H}, \mathrm{CONHPh})$.

General procedure for the synthesis of the 3-(4- acylaminophenyl)- $N$-hydroxy-2-propenamides 1 a-n. 3-[4-(2- Phenylbutyryl)ami- nophenyl]- $N$-hydroxy-2-propenamide (1 c): Ethyl chloroformate (1.2 equiv, $1.38 \mathrm{mmol}, 0.11 \mathrm{~mL}$ ) and $\mathrm{Et}_{3} \mathrm{~N}$ (1.1 equiv, $1.26 \mathrm{mmol}$, $0.17 \mathrm{~mL}$ ) were added to a cooled $\left(0^{\circ} \mathrm{C}\right)$ solution of $6 \mathrm{c}$ (1.0 equiv, $1.15 \mathrm{mmol}, 0.39 \mathrm{~g})$ in dry THF $(10 \mathrm{~mL})$, and the mixture was stirred for $10 \mathrm{~min}$. The solid was filtered off, and 0 -(2-methoxy-2-propyl)hydroxylamine $^{[47]}$ ( 3.0 equiv, $3.45 \mathrm{mmol}, 0.25 \mathrm{~mL}$ ) was added to the filtrate. The solution was stirred for $15 \mathrm{~min}$ at $0{ }^{\circ} \mathrm{C}$, then evaporated under reduced pressure, and the residue was diluted in $\mathrm{MeOH}$ $(10 \mathrm{~mL})$. Amberlyst 15 ion-exchange resin $(115 \mathrm{mg})$ was added to the solution of the O-protected hydroxamate, and the mixture was stirred at RT for $1 \mathrm{~h}$. Afterward, the reaction was filtered and the filtrate was concentrated in vacuo to give the crude $1 \mathrm{c}$, which was purified by crystallization. ${ }^{1} \mathrm{H}$ NMR ( $\left.\left[\mathrm{D}_{6}\right] \mathrm{DMSO}\right): \delta=0.80-0.83(\mathrm{t}, 3 \mathrm{H}$, $\left.\mathrm{PhCHCH}_{2} \mathrm{CH}_{3} \mathrm{CO}\right), 1.66-1.68\left(\mathrm{~m}, 1 \mathrm{H}, \mathrm{PhCHCH}_{2} \mathrm{CH}_{3} \mathrm{CO}\right), 2.03-2.05(\mathrm{~m}$, $\left.1 \mathrm{H}, \mathrm{PhCHCH} \mathrm{CH}_{3} \mathrm{CO}\right), 3.53-3.57(\mathrm{~m}, 1 \mathrm{H}, \mathrm{PhCHCO}), 6.29-6.33(\mathrm{~d}, 1 \mathrm{H}$, $\mathrm{PhCH}=\mathrm{CHCO}), 7.19-7.36(\mathrm{~m}, 5 \mathrm{H}$, benzene and $\mathrm{PhCH}=\mathrm{CHCO}), 7.43-$ $7.45(\mathrm{~m}, 2 \mathrm{H}$, benzene), 7.59-7.61 $(\mathrm{m}, 5 \mathrm{H}$, benzene), $9.05(\mathrm{~s}, 1 \mathrm{H}$, CONHPh), 10.25 (bs, $1 \mathrm{H}, \mathrm{NHOH}), 10.66 \mathrm{ppm}$ (bs, $1 \mathrm{H}, \mathrm{NHOH}$ ); ${ }^{13} \mathrm{C}$ NMR ([D $]$ DMSO $\left.400 \mathrm{MHz}\right): \delta=15.1,29.2,48.2,118.8,121.5$ (2C), 126.0, 128.1, 128.8 (2C), 129.0 (2C), 130.8, 137.7, 139.2, 141.7, $161.6,172.0 \mathrm{ppm}$.

General procedure for the synthesis of $\mathrm{N}$-(2-aminophenyl)-3-(4acylaminophenyl)-2-propenamides 2a-I. $\mathrm{N}$-(2-Aminophenylamino)-3-[4-(2-phenylbutyryl)aminophenyl]-2-propenamide (2c): $\mathrm{Et}_{3} \mathrm{~N}$ (4.0 equiv, $1.93 \mathrm{mmol}, 0.27 \mathrm{~mL}$ ) and BOP reagent (1.2 equiv, 0.57 . mmol, $0.254 \mathrm{~g}$ ) were added under $\mathrm{N}_{2}$ atmosphere to a solution of compound $6 \mathrm{c}$ ( 1.0 equiv, $0.48 \mathrm{mmol}, 0.15 \mathrm{~g}$ ) in dry DMF $(5 \mathrm{~mL})$, and the resulting mixture was stirred for $30 \mathrm{~min}$. After this time, 1,2-phenylendiamine ( 1.0 equiv, $0.48 \mathrm{mmol}, 0.052 \mathrm{~g}$ ) was added, and stirring was continued for a further $30 \mathrm{~min}$. The reaction was quenched by $\mathrm{H}_{2} \mathrm{O}(30 \mathrm{~mL})$ and the precipitate was filtered, washed with $\mathrm{H}_{2} \mathrm{O}(3 \times 30 \mathrm{~mL})$, and dried. The solid residue was subjected to chromatography on silica gel eluting with $\mathrm{EtOAc} / \mathrm{CHCl}_{3} 1: 1$ to provide the desired compound $\mathbf{2} \mathbf{c}$, which was recrystallized from $\mathrm{CH}_{3} \mathrm{CN} / \mathrm{MeOH} . \quad{ }^{1} \mathrm{H} N M R \quad\left(\left[\mathrm{D}_{6}\right] \mathrm{DMSO}\right): \quad \delta=0.84-0.87 \quad(\mathrm{t}, \quad 3 \mathrm{H}$, $\mathrm{PhCHCH}_{2} \mathrm{CH}_{3} \mathrm{CO}$ ), 1.68-1.73 (m, 1 H, PhCHCH $\left.\mathrm{CH}_{3} \mathrm{CO}\right), 2.01-2.07(\mathrm{~m}$, $\left.1 \mathrm{H}, \mathrm{PhCHCH}_{2} \mathrm{CH}_{3} \mathrm{CO}\right), 3.55-3.59(\mathrm{~m}, 1 \mathrm{H}, \mathrm{PhCHCO}), 4.92$ (bs, $2 \mathrm{H}$, $\left.\mathrm{PhNH}_{2}\right), 6.53-6.58(\mathrm{~m}, 1 \mathrm{H}$, aniline), 6.72-6.79 (d, 2H, aniline), 6.87$6.89(\mathrm{~m}, 1 \mathrm{H}$, aniline), 7.23-7.25 (d, $1 \mathrm{H}, \mathrm{PhCH}=\mathrm{CHCO}), 7.30-7.54(\mathrm{~m}$, $8 \mathrm{H}, \mathrm{PhCH}=\mathrm{CHCO}$ and benzene), 7.65-7.67 ( $\mathrm{m}, 2 \mathrm{H}$, benzene), 9.31 (s, $1 \mathrm{H}$, CONHPh), $10.26 \mathrm{ppm}$ (bs, $1 \mathrm{H}, \mathrm{CONH}$ aniline); ${ }^{13} \mathrm{C} \mathrm{NMR}$ ([D $\left.\left.\mathrm{D}_{6}\right] \mathrm{DMSO}, 400 \mathrm{MHz}\right): \delta=15.1,29.2,48.2,114.5,118.8,121.5(2 \mathrm{C})$, $122.8,125.1,126.0,128.1$ (2C), 128.8 (2C), 129.0, (2C), 130.8, 137.7, $139.2,141.7,149.5,168.0,172.0 \mathrm{ppm}$.

General procedure for the synthesis of ethyl 3-[4- (arylmethylamino)phenyl]-2-propenoates 7 a-o. Ethyl 3-[4-(benzofuran-2-ylme-

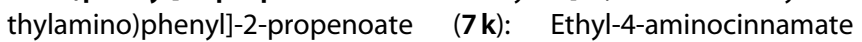
(1.1 equiv, $7.52 \mathrm{mmol}, 1.44 \mathrm{~g}$ ) and $\mathrm{AcOH}(1 \mathrm{~mL})$ were added to a solution of benzofuran-2-carboxaldehyde (1.0 equiv, $6.84 \mathrm{mmol}, 1.0 \mathrm{~g}$ ) in $\mathrm{MeOH}(10 \mathrm{~mL})$, and the resulting mixture was stirred at RT for $1 \mathrm{~h}$. Then the mixture was cooled to $0^{\circ} \mathrm{C}$, and $\mathrm{NaCNBH}_{3}$ (2.0 equiv, $13.68 \mathrm{mmol}, 0.80 \mathrm{~g}$ ) was added. After $30 \mathrm{~min}$, the solvent was removed and the residue was eluted with $\mathrm{H}_{2} \mathrm{O}(50 \mathrm{~mL})$ and extracted with EtOAc $(3 \times 30 \mathrm{~mL})$. The organic layers were washed with a solution of $\mathrm{NaCl}(3 \times 30 \mathrm{~mL})$, dried with $\mathrm{Na}_{2} \mathrm{SO}_{4}$ and concentrated. The organic residue was subjected to chromatography on silica gel eluting with EtOAc/n-hexane $1: 5$, to afford pure product $\mathbf{7} \mathbf{k}$ as a yellow solid that was recrystallized from cyclohexane. ${ }^{1} \mathrm{H}$ NMR $\left(\mathrm{CDCl}_{3}\right): \delta=1.28-1.32\left(\mathrm{t}, 3 \mathrm{H}, \mathrm{OCH}_{2} \mathrm{CH}_{3}\right), 4.19-4.24\left(\mathrm{q}, 2 \mathrm{H}, \mathrm{OCH}_{2} \mathrm{CH}_{3}\right)$, $4.47\left(\mathrm{~s}, 1 \mathrm{H}, \mathrm{ArCH}_{2} \mathrm{NH}\right), 4.49\left(\mathrm{~s}, 2 \mathrm{H}, \mathrm{ArCH}_{2} \mathrm{NH}\right), 6.18-6.22(\mathrm{~d}, 1 \mathrm{H}$, $\mathrm{PhCH}=\mathrm{CHCO}), 6.59(\mathrm{~s}, 1 \mathrm{H}$, benzofuran), 6.64-6.66 $(\mathrm{d}, 2 \mathrm{H}$, benzene), 7.18-7.24 ( $\mathrm{m}, 2 \mathrm{H}$, benzofuran), 7.35-7.37 ( $\mathrm{d}, 2 \mathrm{H}$, benzene), 7.41- 
$7.43(\mathrm{~d}, 1 \mathrm{H}$, benzofuran), 7.47-7.49 $(\mathrm{d}, 1 \mathrm{H}$, benzofuran), 7.55$7.59 \mathrm{ppm}(\mathrm{d}, 1 \mathrm{H}, \mathrm{PhCH}=\mathrm{CHCO})$.

General procedure for the synthesis of 3-[4-(arylalkylamino)phenyl]-2-propenonic acids 8a-0. 3-[4-(Benzofuran-2-ylmethylamino)phenyl]-2-propenoic acid $(\mathbf{8} \mathbf{k})$ : A mixture of $\mathbf{7} \mathbf{k}$ (1.0 equiv, $1.24 \mathrm{mmol}, 0.4 \mathrm{~g}), 2 \mathrm{~N} \mathrm{KOH}(4.96 \mathrm{mmol}, 0.27 \mathrm{~g}, 2.48 \mathrm{~mL})$, and EtOH $(15 \mathrm{~mL})$ was stirred at RT overnight. Afterward, the solution was poured into $\mathrm{H}_{2} \mathrm{O}(50 \mathrm{~mL})$ and extracted with EtOAc $(3 \times 20 \mathrm{~mL}) ; 2 \mathrm{~N}$ $\mathrm{HCl}$ was added to the aqueous layer to reach $\mathrm{pH} 5$, and the obtained precipitate was filtered and dried to give pure compound $8 \mathbf{k}$, which was recrystallized from $\mathrm{CH}_{3} \mathrm{CN}$. ${ }^{1} \mathrm{H}$ NMR ([D $\left.\mathrm{D}_{6}\right] \mathrm{DMSO}$, $400 \mathrm{MHz}): \delta=4.42\left(\mathrm{~s}, 2 \mathrm{H}, \operatorname{ArCH}_{2} \mathrm{NH}\right), 6.12-6.16(\mathrm{~d}, 1 \mathrm{H}, \mathrm{PhCH}=$ $\mathrm{CHCOOH}), 6.55-6.59(\mathrm{~m}, 3 \mathrm{H}$, benzene and benzofuran), 6.85 (bs, $\left.1 \mathrm{H}, \mathrm{PhCH}_{2} \mathrm{NH}\right), 7.14-7.20$ ( $\mathrm{m}, 2 \mathrm{H}$, benzofuran), 7.30-7.45 (m, $5 \mathrm{H}$, benzene, benzofuran and $\mathrm{PhCH}=\mathrm{CHCOOH}), 11.90 \mathrm{ppm}$ (bs, $1 \mathrm{H}$, $\mathrm{COOH})$.

General procedure for the synthesis of 3-[4-(arylalkylamino)phenyl]- $N$-hydroxy-2-propenamides 3 a-o. 3-[4-(Benzofuran-2-ylmethylamino)phenyl]- $\mathrm{N}$-hydroxy-2-propenamide (3 k): Ethyl chloroformate (1.2 equiv, $1.63 \mathrm{mmol}, 0.13 \mathrm{~mL}$ ) and $\mathrm{Et}_{3} \mathrm{~N}$ (1.1 equiv, $1.49 \mathrm{mmol}, 0.21 \mathrm{~mL})$ were added to a cooled $\left(0^{\circ} \mathrm{C}\right)$ solution of $8 \mathrm{k}$ (1.0 equiv, $1.36 \mathrm{mmol}, 0.40 \mathrm{~g})$ in dry THF $(10 \mathrm{~mL})$, and the mixture was stirred for $10 \mathrm{~min}$. The solid was filtered off, and $\mathrm{O}-(2-\mathrm{me}-$ thoxy-2-propyl)hydroxylamine ${ }^{[47]} \quad(3.0$ equiv, $4.08 \mathrm{mmol}, 0.30 \mathrm{~mL}$ ) was added to the filtrate. The solution was stirred for $15 \mathrm{~min}$ at $0{ }^{\circ} \mathrm{C}$, then was evaporated under reduced pressure, and the residue was diluted in $\mathrm{MeOH}(10 \mathrm{~mL})$. Amberlyst 15 ion-exchange resin $(136 \mathrm{mg}$ ) was added to the solution of the O-protected hydroxamate, and the mixture was stirred at RT for $1 \mathrm{~h}$. Afterward, the reaction was filtered and the filtrate was concentrated in vacuo to give the crude $3 \mathbf{k}$, which was purified by crystallization. ${ }^{1} \mathrm{H}$ NMR ([D $\left.\left.\mathrm{D}_{6}\right] \mathrm{DMSO}, 400 \mathrm{MHz}\right): \delta=4.42\left(\mathrm{~s}, 2 \mathrm{H}, \mathrm{ArCH}_{2} \mathrm{NH}\right), 6.10-6.14(\mathrm{~d}, 1 \mathrm{H}$, $\mathrm{PhCH}=\mathrm{CHCO}), 6.55-6.59(\mathrm{~m}, 3 \mathrm{H}$, benzene and benzofuran), 6.85 (bs, $\left.1 \mathrm{H}, \mathrm{PhCH}_{2} \mathrm{NH}\right), 7.14-7.20$ ( $\mathrm{m}, 2 \mathrm{H}$, benzofuran), 7.30-7.45 (m, $5 \mathrm{H}$, benzene, benzofuran, and $\mathrm{PhCH}=\mathrm{CHCO}), 9.00(\mathrm{bs}, 1 \mathrm{H}, \mathrm{NHOH}$ ), $10.85 \mathrm{ppm}$ (bs, $1 \mathrm{H}, \mathrm{NHOH}) ;{ }^{13} \mathrm{C}$ NMR ([D $]$ DMSO, $400 \mathrm{MHz}$ ): $\delta=$ $40.6,102.8,111.5,112.0(2 \mathrm{C}), 118.8,120.9,123.3,123.6,124.7,127.5$, $129.6(2 \mathrm{C}), 141.7,148.5,154.5,154.7,161.6 \mathrm{ppm}$.

General procedure for the synthesis of $\mathrm{N}$-(2-aminophenyl)-3-[4(arylalkylamino)phenyl]acrylamides 4 a-o. $N$-(2-Aminophenyl)-3[4-(benzofuran-2-ylmethylamino)phenyl]acrylamide $\quad(\mathbf{4 k}): \quad \mathrm{Et}_{3} \mathrm{~N}$ (4.0 equiv, $2.04 \mathrm{mmol}, 0.28 \mathrm{~mL}$ ) and BOP reagent (1.2 equiv, 0.61 . mmol, $0.270 \mathrm{~g}$ ) were added under $\mathrm{N}_{2}$ atmosphere to a solution of compound $8 \mathbf{k}$ (1.0 equiv, $0.51 \mathrm{mmol}, 0.15 \mathrm{~g}$ ) in dry DMF $(5 \mathrm{~mL}$ ), and the resulting mixture was stirred for $30 \mathrm{~min}$. After this time, 1,2-phenylendiamine ( 1.0 equiv, $0.51 \mathrm{mmol}, 0.055 \mathrm{~g}$ ) was added and the stirring was continued for a further $30 \mathrm{~min}$. The reaction was quenched by $\mathrm{H}_{2} \mathrm{O}(30 \mathrm{~mL})$ and the precipitate was filtered, washed with $\mathrm{H}_{2} \mathrm{O}(3 \times 30 \mathrm{~mL})$, and dried. The solid residue was subjected to chromatography on silica gel eluting with $\mathrm{EtOAC} / \mathrm{CHCl}_{3}$ $1: 1$ to provide the desired compound $\mathbf{4} \mathbf{k}$, which was recrystallized from $\mathrm{CH}_{3} \mathrm{CN} / \mathrm{MeOH}$. ${ }^{1} \mathrm{H}$ NMR ( $\left[\mathrm{D}_{6}\right] \mathrm{DMSO}, 400 \mathrm{MHz}$ ): $\delta=4.42(\mathrm{~s}, 2 \mathrm{H}$, $\left.\mathrm{ArCH}_{2} \mathrm{NH}\right), 4.86\left(\mathrm{bs}, 2 \mathrm{H}, \mathrm{PhNH}_{2}\right), 6.52-6.58(\mathrm{~m}, 3 \mathrm{H}$, aniline and benzofuran), 6.63-6.65 (d, $2 \mathrm{H}$, benzene), 6.68-6.70 (d, $1 \mathrm{H}, \mathrm{PhCH}=$ CHCO), 6.79-6.81 (t, $1 \mathrm{H}$, aniline), 7.00-7.02 (t, $1 \mathrm{H}$, aniline), 7.14$7.20(\mathrm{~m}, 2 \mathrm{H}$, benzofuran), 7.25-7.40 $(\mathrm{m}, 6 \mathrm{H}$, benzene, benzofuran, $\mathrm{PhCH}=\mathrm{CHCO}$ and $\left.\mathrm{ArCH}_{2} \mathrm{NH}\right), 9.14 \mathrm{ppm}$ (bs, $\left.1 \mathrm{H}, \mathrm{PhNHCO}\right) ;{ }^{13} \mathrm{C}$ NMR ([D $\left.\left.\mathrm{D}_{6}\right] \mathrm{DMSO}, 400 \mathrm{MHz}\right): \delta=40.6,102.8,111.5,112.0(2 \mathrm{C}), 114.5$, $118.8,118.9,120.9,122.8,123.3,123.6,124.7,125.1,125.5,127.5$, 129.6 (2C), 141.7, 148.5, 149.5, 154.5, 154.7, 168.0 ppm.
Enantiomer separations. HPLC enantiomer separations were performed by using stainless steel Chiralpak IA columns $(250 \times 4.6 \mathrm{~mm}$ I.D. and $250 \times 10 \mathrm{~mm}$ I.D.; Daicel, Chemical Industries, Tokyo, Japan). HPLC-grade solvents were supplied by Carlo Erba (Milan, Italy). The HPLC apparatus consisted of a PerkinElmer 200 LC pump (Norwalk, CT, USA) equipped with a Rheodyne injector (Cotati, CA, USA), an HPLC Model TCC-100 oven (Dionex, CA, USA), and a Model 2095 Plus UV/CD detector (Jasco, Ishikawa-cho, Hachioji City, Tokyo, Japan). The sign of optical rotation was monitored online by using a PerkinElmer polarimeter model 241 instrument equipped with $\mathrm{Hg} / \mathrm{Na}$ lamps and a $40 \mu \mathrm{L}$ flow cell.

The mobile phases were filtered and degassed by sonication immediately before use. For analytical enantiomer separations, standard solutions were prepared by dissolving 1-3 mg of sample in $10 \mathrm{~mL}$ mobile phase. The injection volume was $10-20 \mu \mathrm{L}$. In semipreparative enantiomer separation a $1 \mathrm{~mL}$ sample loop was used. After semi-preparative separation, the collected fractions were analyzed by chiral analytical columns to determine their enantiomeric excess (ee). The column hold-up time $\left(t_{0}=3.0 \mathrm{~min}\right.$ for the $250 \times$ $4.6 \mathrm{~mm}$ I.D. column) was determined from the elution of an unretained marker (toluene), using $\mathrm{EtOH}$ as eluent, delivered at a flow rate of $1.0 \mathrm{~mL} \mathrm{~min}{ }^{-1}$. The mobile phase and the corresponding analytical chromatographic data for each resolved compound are summarized as follows: $\mathbf{1}$ b: $n$-hexane/EtOAc/EtOH/TFA 80:20:10:0.1 ( $v /$ $v / v / v), k_{1}=1.48, \alpha=1.36, R_{s}=3.23 ; 1 \mathrm{c}: n$-hexane/EtOAc/EtOH/TFA 80:20:10:0.1 $(\mathrm{v} / \mathrm{v} / \mathrm{v} / \mathrm{v}), k_{1}=1.26, \alpha=1.61, R_{\mathrm{s}}=4.05 ; 2 \mathrm{c}: n$-hexane/ EtOH 30:70 $(v / v), k_{1}=0.73, \alpha=1.66, R_{s}=3.89 ; k_{1}$ : retention factor of the first eluted enantiomer, defined as $\left(t_{1}-t_{0}\right) / t_{0}$ for which $t_{0}$ is the void time of the column; $\alpha$ : enantioselectivity factor, defined as $k_{2} /$ $k_{1} ; R_{\mathrm{s}}$ : resolution factor, defined as $2\left(t_{2}-t_{1}\right) /\left(w_{1}+w_{2}\right)$, where $t_{1}$ and $t_{2}$ are retention times and $w_{1}$ and $w_{2}$ are band widths at the baseline in time units. Other analytical chromatographic conditions: flow rate: $1.0 \mathrm{~mL} \mathrm{~min}^{-1}$; temperature: $25^{\circ} \mathrm{C}$; detector: $U V$ at $\lambda 300 \mathrm{~nm}$.

Specific rotations were measured at $\lambda 589 \mathrm{~nm}$ by a PerkinElmer polarimeter model 241 instrument equipped with a Na lamp. The volume of the cell was $1 \mathrm{~mL}$, and the optical path was $10 \mathrm{~cm}$. The system was at a temperature of $20^{\circ} \mathrm{C}$, maintained by a Neslab RTE 740 cryostat. The circular dichroism (CD) spectra of the enantiomers of $\mathbf{1} \mathbf{b}$ and $\mathbf{1} \mathbf{c}$, dissolved in $\mathrm{EtOH}$, in a quartz cell $(0.1 \mathrm{~cm}$ path length) at $25^{\circ} \mathrm{C}$, were measured using a Jasco Model J-700 spectropolarimeter. The spectra were averaged over three instrumental scans, and the intensities are presented in terms of ellipticity (mdeg).

\section{Homology models, molecular modeling, and docking studies}

All molecular modeling software were run on a Beowulf cluster running the operating system, that is, a GNU/Linux Debian 5.0Lenny using MPI (Message Passing Interface) libraries for parallel processes.

HDAC1 model preparation. The HDAC1 structure was prepared using the deposited sequence in the Universal Protein Resource ${ }^{[58]}$ (UniProt; entry code: Q13547) The homology model was automatically obtained by feeding the Protein Model Portal (PMP) Server ${ }^{[59]}$ with the above sequences. The PMP returned a HDAC1 model made using the HDAC2/N-(4-aminobiphenyl-3-yl)benzamide complex ${ }^{[49]}$ chain B as template (PDB ID: 3MAX, $94 \%$ sequence identity). The model was then refined by the Amber 8.0 program using the following protocol. First, the experimental bound conformation of $\mathrm{N}$-(4-aminobiphenyl-3-yl)benzamide as found in the template 
was merged into the HDAC1 structure. AM1-BCC charges were calculated on the ligand using the antechamber module of Amber 8.0 using the xLeap Amber module, hydrogen atoms were added to the starting complex, and solvated in a octahedral box of TIP3P water with each box side at least $10.0 \AA$ away from the nearest atoms of the complex. Sodium ions were included to neutralize the charge of the system. The ions were placed randomly in the system $10 \AA$ away from the nearest atoms. The hydrogen atoms, counter-ions, and water molecules were then minimized for 1000 iterations. Finally the whole complex was relaxed for 5000 iterations.

HDAC4 preparation. HDAC4 structures $^{[50]}$ were retrieved from RCSB PDB (PDB IDs: 2VQJ and 2VQM) co-crystallized with a trifluoromethylketone and hydroxamic acid inhibitors. The structures were refined by the Amber 8.0 program using the protocol described previously for HDAC1.

Docking procedure. The docking studies were performed using AutoDock 4.2. The proteins, prepared as described above, (HDAC1 and HDAC4) were aligned by means of the UCSF Chimera ${ }^{[60]}$ MatchMaker tool. The structure of the inhibitors to be docked were built by the Chemaxon sketch module. ${ }^{[61]}$ AutoDock Tools package 1.5.4 (http://mgltools.scripps.edu/) was used to generate the docking input files and to analyze the docking results; the same procedure as described in the manual was followed. A grid box size of $51 \times 58 \times 57$ points spacing of $0.375 \AA$ were used, centered on the bound co-crystallized inhibitors and covered most of the catalytic channels of the enzymes. Two hundred structures, that is, 200 runs, were generated using a Lamarckian genetic algorithm. A default protocol was applied, with an initial population of 150 randomly placed individuals, a maximum number of $2.5 \times 10^{6}$ energy evaluations, and a maximum number of $2.7 \times 10^{4}$ generations. A mutation rate of 0.02 and a crossover rate of 0.8 were used. The docking results were clustered using a $2.0 \AA$ tolerance. In all cases the lowest energy docked conformation belonged to the most populated cluster. In the case of HDAC4 100 runs for each structure were generated (cross-Docking ${ }^{[2]}$ ) and the results of either set of dockings were clustered using the AutoDock internal clustering algorithm.

\section{Biology}

In vitro maize HD1-B and HD1-A enzyme inhibition. Radioactively labeled chicken core histones were used as the enzyme substrate according to established procedures. Purification of maize HD1-A and HD1-B enzymes was performed in part as recently described. ${ }^{[63-66]}$ Briefly, frozen seedlings of maize were ground to powder in a mortar. Chromatin was prepared as previously described ${ }^{[67]}$ which results in a soluble cytoplasmic fraction that contains HD1-A and a "chromatin fraction" that contains HD1-B. Cytoplasmic and nuclear fractions were further separated by ion exchange chromatography (Q-Sepharose) with subsequent size exclusion chromatography (S200). Resulting protein fractions with HDAC activity were used for inhibition assays. The enzymatic activity liberated tritiated acetic acid from the substrate, which was quantified by scintillation counting. $I C_{50}$ values are determined on the basis of three replications. A $50 \mu \mathrm{L}$ sample of partially purified endogenous (native) maize enzymes was incubated $\left(30 \mathrm{~min}, 30^{\circ} \mathrm{C}\right.$ ) with $10 \mu \mathrm{L}$ of total $\left[{ }^{3} \mathrm{H}\right]$ acetate-pre-labeled chicken reticulocyte histones $\left(2 \mathrm{mg} \mathrm{mL}^{-1}\right)$. The reaction was stopped by addition of $36 \mu \mathrm{L}$ of $1 \mathrm{M} \mathrm{HCl} / 0.4 \mathrm{M}$ acetate and $800 \mu \mathrm{L}$ EtOAc. After centrifugation $(10000 \mathrm{~g}, 5 \mathrm{~min})$, a $600 \mu \mathrm{L}$ aliquot of the upper phase was counted for radioactivity in $3 \mathrm{~mL}$ liquid scintillation cocktail. The com- pounds were tested at a starting concentration of $40 \mu \mathrm{M}$, and active substances were further diluted. SAHA and HDAC42 were used as the reference compounds, and blank solvents were used as negative controls.

Fluorimetric human recombinant HDAC1 and HDAC4 assays. The HDAC fluorescent activity assay for HDAC1 and HDAC4 is based on the Fluor de Lys Substrate and Developer combination (BioMol), and was carried out according to the supplier's instructions and as previously reported. ${ }^{[68]}$ First, the inhibitors and purified recombinant HDAC1 or HDAC4 enzymes were pre-incubated at RT for 15 min before addition of the Fluor de Lys Substrate, which comprises an acetylated lysine side chain. For the HDAC4 assay, the HDAC4-selective, non-histone substrate reported by Lahm et al. ${ }^{[48]}$ was used. Full-length HDAC1 and HDAC4 with C-terminal His tag were expressed using baculovirus systems. Deacetylation sensitizes the substrates that, in the second step, treated with the developer produce a fluorophore. Fluorescence was quantified with a TECAN Infinite M200 station. $I_{50}$ data were analyzed using GraphPad Prism Software.

Cellular assays: Cell lines and cultures. Cells from the U937 cell line were cultured in RPMI with $10 \%$ fetal calf serum, $100 \mathrm{UmL}^{-1}$ penicillin, $100 \mu \mathrm{g} \mathrm{mL}^{-1}$ streptomycin, and $250 \mathrm{ng} \mathrm{mL}^{-1}$ amphotericin-B, $10 \mathrm{~mm}$ HEPES, and $2 \mathrm{~mm}$ glutamine. The U937 cells were kept at a constant concentration of $2 \times 10^{5}$ cells $(\mathrm{mL} \text { culture medium })^{-1}$.

Ligands and materials. SAHA, MS-275, HDAC42, and the cinnamylbased compounds 1-4 were dissolved in DMSO and used at $5 \mu \mathrm{M}$ as described. ${ }^{[68]}$

Histone $\mathrm{H} 3$ and $\alpha$-tubulin acetylation in U937 cells. For quantification of histone $\mathrm{H} 3$ acetylation, $5 \mu \mathrm{g}$ total histone extracts were separated on a $15 \%$ polyacrylamide gel and blotted as described. ${ }^{[68]}$ Western blots were shown for acetylated histone H3 (Upstate), and histone $\mathrm{H} 1$ (Abcam) was used to normalize for equal loading. For determination of $\alpha$-tubulin acetylation, $25 \mu \mathrm{g}$ total protein extracts were separated on a $10 \%$ polyacrylamide gel and blotted as described. $^{[67]}$ Western blots were shown for acetylated $\alpha$-tubulin (Sigma) and total ERKs (Santa Cruz) were used to normalize for equal loading.

Determination of $p 21^{\text {WAF } / / \text { IP } 1}$ induction in U937 cells. Total protein extracts $(100 \mu \mathrm{g})$ were separated on a $15 \%$ polyacrylamide gel and blotted as previously described. ${ }^{[69,70]}$ Western blots were shown for p21 (Transduction Laboratories) and total ERKs (Santa Cruz) were used to normalize for equal loading.

Cell-cycle analysis using U937 cells. $2.5 \times 10^{5}$ cells were collected and resuspended in $500 \mu \mathrm{L}$ hypotonic buffer $(0.1 \%$ Triton X-100, $0.1 \%$ sodium citrate, $50 \mu \mathrm{g} \mathrm{mL}^{-1}$ propidium iodide (PI), RNAse A). Cells were incubated in the dark for $30 \mathrm{~min}$. Samples were acquired on a FACS-Calibur flow cytometer using the Cell Quest software (Becton Dickinson) and analyzed using standard procedures using the Cell Quest software (Becton Dickinson) and ModFit LT ver. 3 software (Verity) as previously reported ${ }^{[69]}$ All the experiments were performed three times.

FACS analysis of apoptosis in U937 cells. Apoptosis was measured with the caspase 3-7 detection (B-Bridge) method; samples were analyzed by FACS with Cell Quest technology (Becton Dickinson) as previously reported. ${ }^{[70]}$

Proliferation assay in U937 cells. U937 cells were cultured in 24-well plates (Corning) at an initial dilution of $2 \times 10^{5}$ cells $\mathrm{mL}^{-1}$ with vehicle or with HDAC inhibitors used at the indicated concentrations. Every 24 h, living U937 cells were counted using the Trypan Blue 
dye (Sigma) for dead cells staining. The graph (Figure 8) shows data plotted after three days. The experiment was carried out in triplicate. In parallel, an MTT colorimetric proliferation assay (Promega) was carried out in duplicate (data not shown) following the manufacturer's instructions.

Granulocytic differentiation in U937 cells. Granulocytic differentiation was carried out as previously described. ${ }^{[70]}$ Briefly, U937 cells were harvested and resuspended in $10 \mu \mathrm{L}$ phycoerythrin-conjugated CD11c (CD11c-PE). Control samples were incubated with $10 \mu \mathrm{L} \mathrm{PE}$ conjugated mouse IgG1 for $30 \mathrm{~min}$ at $4^{\circ} \mathrm{C}$ in the dark, washed in PBS, and resuspended in $500 \mu \mathrm{L}$ PBS containing PI $\left(0.25 \mu \mathrm{g} \mathrm{m}^{-1}\right)$. Samples were analyzed by FACS with Cell Quest technology (Becton Dickinson). PI-positive cells were excluded from the analysis.

\section{Acknowledgements}

This work was partially supported by grants from Fondazione Roma (A.M.), DAC s.r.I. (A.M.), PRIN2008 (R.R.), EU (518417, "Epitron", 221952, "ATLAS") (L.A.), and AIRC (L.A.).

Keywords: 2-aminoanilides - apoptosis - cytodifferentiation histone deacetylases $\cdot$ hydroxamates

[1] A. P. Wolffe, D. Guschin, J. Struct. Biol. 2000, 129, 102-122.

[2] T. Kouzarides, Cell 2007, 128, 693-705.

[3] A. J. Ruthenburg, H. Li, D. J. Patel, C. D. Allis, Nat. Rev. Mol. Cell Biol. 2007, 8, 983-994.

[4] W. L. Cheung, S. D. Briggs, C. D. Allis, Curr. Opin. Cell Biol. 2000, 12, $326-$ 333.

[5] S. K. Kurdistani, M. Grunstein, Nat. Rev. Mol. Cell Biol. 2003, 4, 276-284.

[6] A. L. Clayton, C. A. Hazzalin, L. C. Mahadevan, Mol. Cell 2006, 23, 289 296

[7] X. J. Yang, E. Seto, Oncogene 2007, 26, 5310-5318.

[8] L. Lafon-Hughes, M. V. Di Tomaso, L. Mendez-Acuna, W. Martinez-Lopez, Mutat. Res. 2008, 658, $191-214$.

[9] J. E. Bolden, M. J. Peart, R. W. Johnstone, Nat. Rev. Drug Discovery 2006 5, 769-784.

[10] S. Minucci, P. G. Pelicci, Nat. Rev. Cancer 2006, 6, 38-51.

[11] M. A. Glozak, E. Seto, Oncogene 2007, 26, 5420-5432.

[12] M. T. Epping, R. Bernards, Int. J. Biochem. Cell Biol. 2009, 41, 16-20.

[13] A. Mai, L. Altucci, Int. J. Biochem. Cell Biol. 2009, 41, 199-213.

[14] P. A. Marks, R. Breslow, Nat. Biotechnol. 2007, 25, 84-90.

[15] C. Campas-Moya, Drugs Today 2009, 45, 787-795.

[16] A. Tomillero, M. A. Moral, Methods Find. Exp. Clin. Pharmacol. 2009, 31 263.

[17] J. Tan, S. Cang, Y. Ma, R. L. Petrillo, D. Liu, J. Hematol. Oncol. 2010, 3,5

[18] H. M. Prince, M. J. Bishton, S. J. Harrison, Clin Cancer Res. 2009, 15, 3958-3969.

[19] T. A. Miller, D. J. Witter, S. Belvedere, J. Med. Chem. 2003, 46, 5097 5116.

[20] A. Mai, S. Massa, D. Rotili, I. Cerbara, S. Valente, R. Pezzi, S. Simeoni, R. Ragno, Med. Res. Rev. 2005, 25, 261-309.

[21] D. C. Coffey, M. C. Kutko, R. D. Glick, L. M. Butler, G. Heller, R. A. Rifkind, P. A. Marks, V. M. Richon, M. P. La Quaglia, Cancer Res. 2001, 61, 3591 3594.

[22] D. K. Kim, J. Y. Lee, J. S. Kim, J. H. Ryu, J. Y. Choi, J. W. Lee, G. J. Im, T. K Kim, J. W. Seo, H. J. Park, J. Yoo, J. H. Park, T. Y. Kim, Y. J. Bang, J. Med. Chem. 2003, 46, 5745-5751.

[23] J. H. Park, Y. Jung, T. Y. Kim, S. G. Kim, H. S. Jong, J. W. Lee, D. K. Kim, J. S. Lee, N. K. Kim, Y. J. Bang, Clin. Cancer Res. 2004, 10, $5271-5281$.

[24] K. W. Lee, J. H. Kim, J. H. Park, H. P. Kim, S. H. Song, S. G. Kim, T. Y. Kim, H. S. Jong, K. H. Jung, S. A. Im, T. Y. Kim, N. K. Kim, Y. J. Bang, Anticancer Res. 2006, 26, 3429-3438.
[25] Q. Lu, Y. T. Yang, C. S. Chen, M. Davis, J. C. Byrd, M. R. Etherton, A. Umar, J. Med. Chem. 2004, 47, 467-474.

[26] S. Mahboobi, A. Sellmer, H. Hocher, C. Garhammer, H. Pongratz, T. Maier, T. Ciossek, T. Beckers, J. Med. Chem. 2007, 50, 4405-4418.

[27] O. Moradei, S. Leit, N. Zhou, S. Frechette, I. Paquin, S. Raeppel, F. Gaudette, G. Bouchain, S. H. Woo, A. Vaisburg, M. Fournel, A. Kalita, A. Lu, M. C. Trachy-Bourget, P. T. Yan, J. Liu, Z. Li, J. Rahil, A. R. MacLeod, J. M. Besterman, D. Delorme, Bioorg. Med. Chem. Lett. 2006, 16, 4048-4052.

[28] A. Vaisburg, I. Paquin, N. Bernstein, S. Frechette, F. Gaudette, S. Leit, O. Moradei, S. Raeppel, N. Zhou, G. Bouchain, S. H. Woo, Z. Jin, J. Gillespie, J. Wang, M. Fournel, P. T. Yan, M. C. Trachy-Bourget, M. F. Robert, A. Lu, J. Yuk, J. Rahil, A. R. Macleod, J. M. Besterman, Z. Li, D. Delorme, Bioorg. Med. Chem. Lett. 2007, 17, 6729-6733.

[29] Q. Lu, D. S. Wang, C. S. Chen, Y. D. Hu, J. Med. Chem. 2005, 48, 5530 5535 .

[30] S. K. Kulp, C. S. Chen, D. S. Wang, C. Y. Chen, Clin. Cancer Res. 2006, 12, 5199-5206.

[31] Y. S. Lu, Y. Kashida, S. K. Kulp, Y. C. Wang, D. Wang, J. H. Hung, M. Tang Z. Z. Lin, T. J. Chen, A. L. Cheng, C. S. Chen, Hepatology 2007, 46, 11191130.

[32] C. S. Chen, Y. C. Wang, H. C. Yang, P. H. Huang, S. K. Kulp, C. C. Yang, Y. S. Lu, S. Matsuyama, C. Y. Chen, Cancer Res. 2007, 67, 5318-5327.

[33] A. M. Sargeant, R. C. Rengel, S. K. Kulp, R. D. Klein, S. K. Clinton, Y. C. Wang, C. S. Chen, Cancer Res. 2008, 68, 3999-4009.

[34] Y. T. Yang, C. Balch, S. K. Kulp, M. R. Mand, K. P. Nephew, C. S. Chen, Neoplasia 2009, 11, 552-563, 3 pp. following 563.

[35] N. L. Steele, J. A. Plumb, L. Vidal, J. Tjornelund, P. Knoblauch, A. Rasmussen, C. E. Ooi, P. Buhl-Jensen, R. Brown, T. R. Evans, J. S. DeBono, Clin. Cancer Res. 2008, 14, 804-810.

[36] E. M. Ocio, D. Vilanova, P. Atadja, P. Maiso, E. Crusoe, D. FernándezLázaro, M. Garayoa, L. San-Segundo, T. Hernández-Iglesias, E. de Alava, W. Shao, Y. M. Yao, A. Pandiella, J. F. San-Miguel, Haematologica 2010 95, 794-803.

[37] A. Mai, S. Massa, R. Ragno, I. Cerbara, F. Jesacher, P. Loidl, G. Brosch, J. Med. Chem. 2003, 46, 512-524.

[38] A. Mai, S. Massa, R. Pezzi, S. Simeoni, D. Rotili, A. Nebbioso, A. Scognamiglio, L. Altucci, P. Loidl, G. Brosch, J. Med. Chem. 2005, 48, $3344-$ 3353.

[39] A. Mai, S. Massa, S. Valente, S. Simeoni, R. Ragno, P. Bottoni, R. Scatena, G. Brosch, ChemMedChem 2006, 1, 225-237.

[40] A. Mai, S. Valente, D. Rotili, S. Massa, G. Botta, G. Brosch, M. Miceli, A Nebbioso, L. Altucci, Int. J. Biochem. Cell Biol. 2007, 39, 1510-1522.

[41] A. Mai, S. Valente, A. Nebbioso, S. Simeoni, R. Ragno, S. Massa, G. Brosch, F. De Bellis, F. Manzo, L. Altucci, Int. J. Biochem. Cell Biol. 2009, 41, 235-247.

[42] S. Valente, M. Conte, M. Tardugno, S. Massa, A. Nebbioso, L. Altucci, A. Mai, ChemMedChem 2009, 4, 1411-1415.

[43] A. Mai, S. Massa, R. Pezzi, S. Valente, P. Loidl, G. Brosch, Med. Chem. 2005, 1, 245-254.

[44] F. Thaler, A. Colombo, A. Mai, R. Amici, C. Bigogno, R. Boggio, A. Cappa, S. Carrara, T. Cataudella, F. Fusar, E. Gianti, S. J. di Ventimiglia, M. Moroni, D. Munari, G. Pain, N. Regalia, L. Sartori, S. Vultaggio, G. Dondio, S. Gagliardi, S. Minucci, C. Mercurio, M. Varasi, J. Med. Chem. 2010, 53, $822-$ 839.

[45] F. Thaler, M. Varasi, A. Colombo, R. Boggio, D. Munari, N. Regalia, M. G. Rozio, V. Reali, A. E. Resconi, A. Mai, S. Gagliardi, G. Dondio, S. Minucci, C. Mercurio, ChemMedChem 2010, 5, 1359-1372.

[46] A. Mai, A. Perrone, A. Nebbioso, D. Rotili, S. Valente, M. Tardugno, S. Massa, F. De Bellis, L. Altucci, Bioorg. Med. Chem. Lett. 2008, 18, 2530 2535.

[47] K. Mori, K. Koseki, Tetrahedron 1988, 44, 6013-6020.

[48] A. Lahm, C. Paolini, M. Pallaoro, M. C. Nardi, P. Jones, P. Neddermann, S. Sambucini, M. J. Bottomley, P. Lo Surdo, A. Carfi, U. Koch, R. De Francesco, C. Steinkuhler, P. Gallinari, Proc. Natl. Acad. Sci. USA 2007, 104, $17335-17340$.

[49] J. C. Bressi, A. J. Jennings, R. Skene, Y. Wu, R. Melkus, R. De Jong, S. O'Connell, C. E. Grimshaw, M. Navre, A. R. Gangloff, Bioorg. Med. Chem. Lett. 2010, 20, 3142-3145.

[50] M. J. Bottomley, P. Lo Surdo, P. Di Giovine, A. Cirillo, R. Scarpelli, F. Ferrigno, P. Jones, P. Neddermann, R. De Francesco, C. Steinkuhler, P. Gallinari, A. Carfi, J. Biol. Chem. 2008, 283, 26694-26704. 
[51] D. F. Wang, O. Wiest, P. Helquist, H. Y. Lan-Hargest, N. L. Wiech, J. Med. Chem. 2004, 47, 3409-3417.

[52] L. C. Sambucetti, D. D. Fischer, S. Zabludoff, P. O. Kwon, H. Chamberlin, N. Trogani, H. Xu, D. Cohen, J. Biol. Chem. 1999, 274, 34940-34947.

[53] G. Zupkovitz, R. Grausenburger, R. Brunmeir, S. Senese, J. Tischler, J. Jurkin, M. Rembold, D. Meunier, G. Egger, S. Lagger, S. Chiocca, F. Propst, G. Weitzer, C. Seiser, Mol. Cell Biol. 2010, 30, 1171-1181.

[54] A. Mai, Expert Opin. Ther. Targets 2007, 11, 835-851.

[55] R. W. Johnstone, Nat. Rev. Drug Discovery 2002, 1, 287-299.

[56] A. Mai, M. Esposito, G. Sbardella, S. Massa, Org. Prep. Proced. Int. 2001, 33, $391-394$.

[57] T. Suzuki, T. Ando, K. Tsuchiya, N. Fukazawa, A. Saito, Y. Mariko, T. Yamashita, O. Nakanishi, J. Med. Chem. 1999, 42, $3001-3003$.

[58] E. Boutet, D. Lieberherr, M. Tognolli, M. Schneider, A. Bairoch, Methods Mol. Biol. 2007, 406, 89-112.

[59] K. Arnold, F. Kiefer, J. Kopp, J. N. Battey, M. Podvinec, J. D. Westbrook H. M. Berman, L. Bordoli, T. Schwede, J. Struct. Funct. Genomics 2009, 10, $1-8$.

[60] E. F. Pettersen, T. D. Goddard, C. C. Huang, G. S. Couch, D. M. Greenblatt E. C. Meng, T. E. Ferrin, J. Comput. Chem. 2004, 25, 1605-1612.

[61] F. Csizmadia, J. Chem. Inf. Comput. Sci. 2000, 40, 323-324.

[62] I. Musmuca, A. Caroli, A. Mai, N. Kaushik-Basu, P. Arora, R. Ragno, J. Chem. Inf. Model 2010, 50, 662-676.
[63] G. Brosch, M. Goralik-Schramel, P. Loidl, FEBS Lett. 1996, 393, 287-291.

[64] G. Brosch, A. Lusser, M. Goralik-Schramel, P. Loidl, Biochemistry 1996, 35, $15907-15914$

[65] D. Kolle, G. Brosch, T. Lechner, A. Lusser, P. Loidl, Methods 1998, 15, $323-331$.

[66] T. Lechner, A. Lusser, G. Brosch, A. Eberharter, M. Goralik-Schramel, P. Loidl, Biochim. Biophys. Acta 1996, 1296, $181-188$.

[67] K. Steinmüller, K. Apel, Plant Mol. Biol. 1986, 7, 87-94.

[68] A. Nebbioso, F. Manzo, M. Miceli, M. Conte, L. Manente, A. Baldi, A. De Luca, D. Rotili, S. Valente, A. Mai, A. Usiello, H. Gronemeyer, L. AltucCi, EMBO Rep. 2009, 10, 776-782.

[69] A. Nebbioso, N. Clarke, E. Voltz, E. Germain, C. Ambrosino, P. Bontempo, R. Alvarez, E. M. Schiavone, F. Ferrara, F. Bresciani, A. Weisz, A. R. de Lera H. Gronemeyer, L. Altucci, Nat. Med. 2005, 11, 77-84.

[70] L. Altucci, A. Rossin, W. Raffelsberger, A. Reitmair, C. Chomienne, H. Gronemeyer, Nat. Med. 2001, 7, 680-686.

Received: December 11, 2010

Revised: January 19, 2011

Published online on March 4, 2011 